Prepared in cooperation with

U.S. Department of Agriculture, Forest Service

\title{
Estimating the Magnitude of Bankfull Flows for Streams in Idaho
}

\section{Water-Resources Investigations Report 03-4261}

\section{U.S. Department of the Interior \\ U.S. Geological Survey}

The following errors were corrected on June 16, 2004: Page 6, table 2, description of basin slope, "feet per mile" was changed to "percent"; Page 9, table 3, headnote, basin slope in "feet per mile" was changed to basin slope in "percent"; Page 17, appendix A, headnote, "feet per mile" was removed. 


\section{Estimating the Magnitude of Bankfull Flows for Streams in Idaho}

By Jon E. Hortness and Charles Berenbrock

Water-Resources Investigations Report 03-4261

U.S. Department of the Interior

U.S. Geological Survey 


\section{U.S. Department of the Interior Gale A. Norton, Secretary}

\author{
U.S. Geological Survey \\ Charles G. Groat, Director
}

U.S. Department of Agriculture

Ann M. Veneman, Secretary

U.S. Forest Service

Dale Bosworth, Chief

U.S. Geological Survey, Reston, Virginia; 2004

For more information about the USGS and its products:

Telephone: 1-888-ASK-USGS

World Wide Web: http:// www.usgs.gov/

\begin{abstract}
Any use of trade, product, or firm names in this publication is for descriptive purposes only and does not imply endorsement by the U.S. Government.

Although this report is in the public domain permission must be secured from the individual copyright owners to reproduce any copyrighted materials contained within this report.
\end{abstract}

Hortness, J.E., and Berenbrock, Charles, 2004, Estimating the Magnitude of Bankfull Flows for Streams in Idaho: U.S. Geological Survey Water-Resources Investigations Report 03-4261, 37 p. 


\section{Contents}

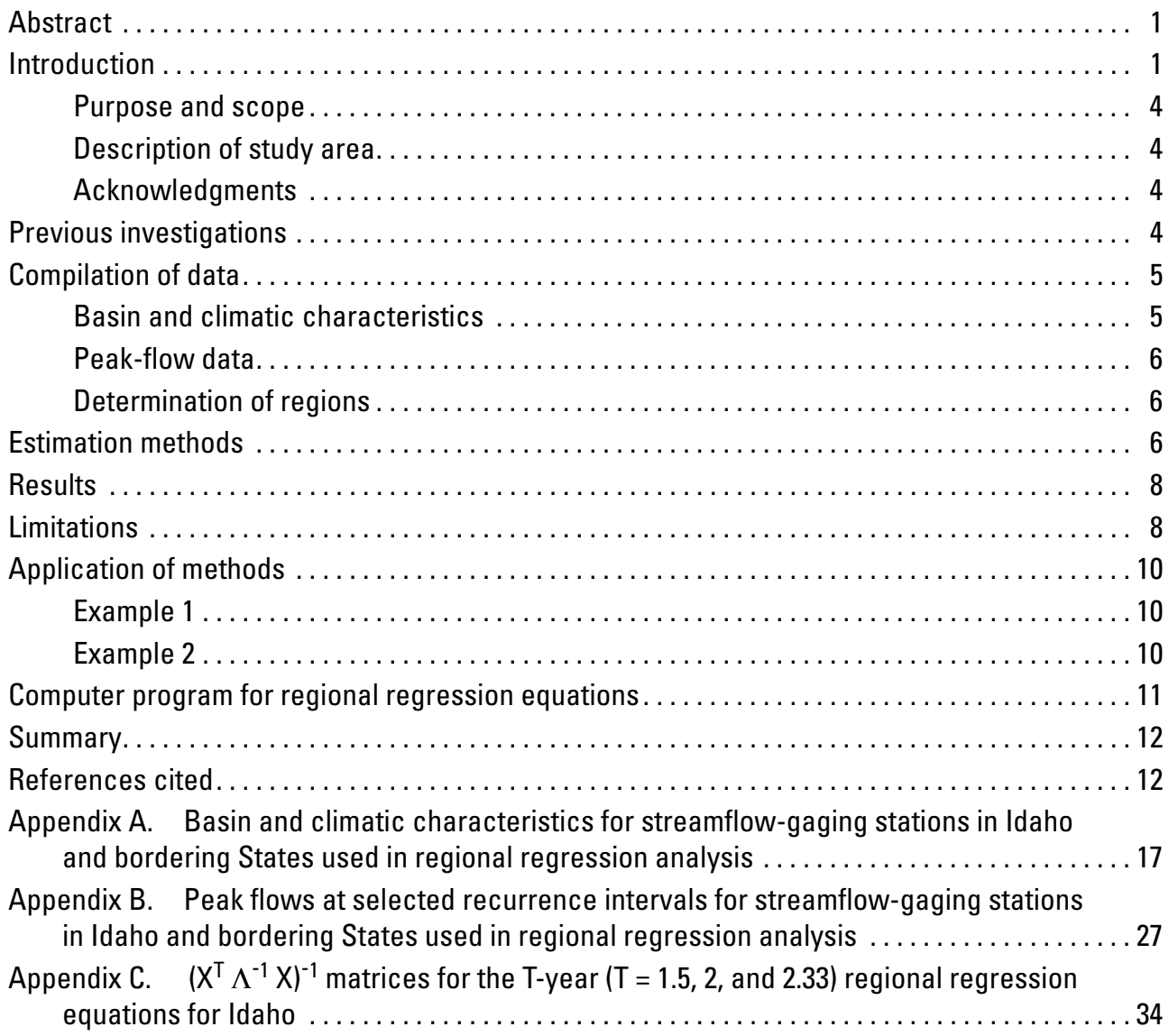




\section{Figures}

1. Map showing locations of streamflow-gaging stations in Idaho and bordering States used in regional regression analysis.

2. Map showing locations of regions in Idaho used in regional regression analysis ....

3. Graph showing joint distribution of drainage area and mean basin elevation, and minimum covering ellipsoid for gaged sites in region 3 , Idaho ...

\section{Tables}

1. Selected data sources used to obtain basin and climatic characteristics for regional regression analysis

2. Description of selected basin and climatic characteristics used in the final predictive equations

3. Predictive regression equations and their accuracy in estimating peak flows for ungaged sites on unregulated and undiverted streams in Idaho

Conversion Factors, Water Year Definition, and Vertical Datum

\begin{tabular}{lcl}
\hline Multiply & By & To obtain \\
\hline cubic foot per second $\left(\mathrm{ft}^{3} / \mathrm{s}\right)$ & 0.02832 & cubic meter per second $\left(\mathrm{m}^{3} / \mathrm{s}\right)$ \\
foot (ft) & 0.3048 & meter $(\mathrm{m})$ \\
foot per mile (ft/mi) & 0.1894 & meter per kilometer $(\mathrm{m} / \mathrm{km})$ \\
inch (in.) & 2.54 & centimeter $(\mathrm{cm})$ \\
inch per year (in/yr) & 2.54 & centimeter per year $(\mathrm{cm} / \mathrm{yr})$ \\
mile (mi) & 1.609 & kilometer $(\mathrm{km})$ \\
square mile $\left(\mathrm{mi}^{2}\right)$ & 2.590 & square kilometer $\left(\mathrm{km}^{2}\right)$ \\
\hline
\end{tabular}

Water year: In U.S. Geological Survey reports dealing with surface-water supply, a water year is the 12-month period, 0 ctober 1 through September 30 . The water year is designated by the calendar year in which it ends; thus, the water year ending September 30, 2001, is called the "2001 water year."

Sea Level: In this report, "sea level" refers to the North American Vertical Datum of 1988 (NAVD of 1988) - a vertical control datum established by the minimum-constraint adjustment of Canadian-Mexican-United States leveling observations and held fixed at Father Point/Rimouski, Quebec, Canada. 


\title{
Estimating the Magnitude of Bankfull Flows for Streams in Idaho
}

\author{
By Jon E. Hortness and Charles Berenbrock
}

\begin{abstract}
Methods for estimating magnitudes of peak flows with recurrence intervals of 1.5 and 2.33 years were developed for ungaged sites on streams throughout Idaho. These peak flows represent the magnitudes at and near bankfull stage and are needed for quantification of water rights required to maintain or restore fish and wildlife habitats and riparian vegetation. Data from a previous report detailing methods for estimating magnitudes with recurrence intervals of 2 to 500 years were used in this study.

Generalized least-squares regression techniques were used to calculate the final coefficients and measures of accuracy for the regression equations for each of nine regions. The equations relate basin and climatic characteristics to peak flows with recurrence intervals of 1.5 and 2.33 years. The basin and climatic characteristics used to develop the equations included drainage area, mean basin elevation, forested area, mean annual precipitation, basin slope, north-facing slopes greater than 30 percent, and slopes greater than 30 percent. Average standard errors of the regression model ranged from +150 to -60.1 percent, and average standard errors of prediction ranged from +165 to -62.2 percent. The range of prediction errors was narrowest, -48.9 to-32.9 percent, for region 5 .
\end{abstract}

A computer program was developed to automate the calculations required for the regional regression calculations. Results from this program comprised calculated peak flows, site-specific standard errors of prediction, and the 90-percent confidence intervals for the estimates.

\section{INTRODUCTION}

Estimates of the magnitude and frequency of peak flows are used for a variety of purposes, such as the design of bridges, culverts, and flood-control structures, and the management and regulation of flood plains. For these purposes, peak-flow recurrence intervals generally are 50 years or greater. However, there is increasing interest in peak flows with a more frequent recurrence interval and their role in maintaining aquatic and riparian ecosystems. Of particular interest are those peak flows necessary for mobilization of streambed sediments to maintain long-term fish habitat and channel capacity.

The U.S. Forest Service (USFS) in Idaho has been involved in the quantification of instream flows as part of the ongoing Snake River Basin Adjudication, as well as for general planning and administrative purposes. One key component of instream flows proposed by the Forest Service is the high flow regime necessary to sustain long-term aquatic and riparian ecosystems. Methods used to estimate the range of flows that constitute this high flow regime include using bankfull discharge or a percentage of bankfull discharge.

Most hydrologists agree that peak flows with a recurrence interval of about 1.5 years best represent bankfull flows. Leopold (1994) stated that the recurrence interval of bankfull discharges generally ranges from 1 to 2.5 years and that the 1.5 -year peak flow is a reasonable average. Similarly, a regional study completed by Castro and Jackson (2001) suggests that the average recurrence interval for bankfull flows in the Pacific Northwest States (Oregon, Washington, and Idaho) is 1.4 years, and the 1.5-year interval is suggested for use in Idaho. Emmett (1975) also found that the average recurrence interval for bankfull discharges in the upper Salmon River Basin is about 1.5 years.

Currently, peak-flow recurrence interval information is available only for gaged sites (sites where streamflow-gaging stations, or gages, have been established) that have at least 10 years of annual peak-flow record. Berenbrock (2002) developed regional peakflow regression equations for ungaged streams in Idaho; however, the minimum recurrence interval for 

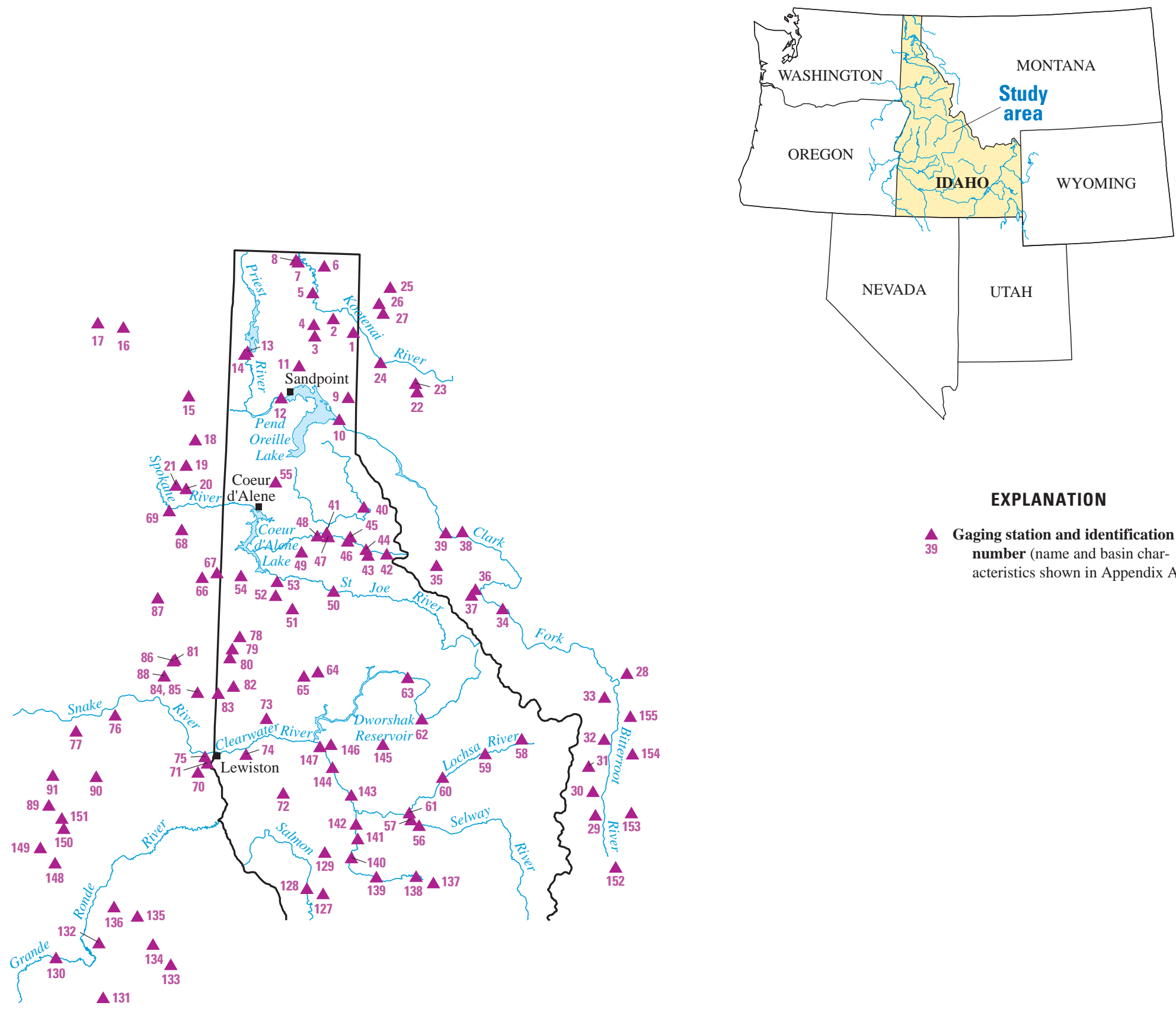

\section{EXPLANATION}

A Gaging station and identification number (name and basin characteristics shown in Appendix A) 


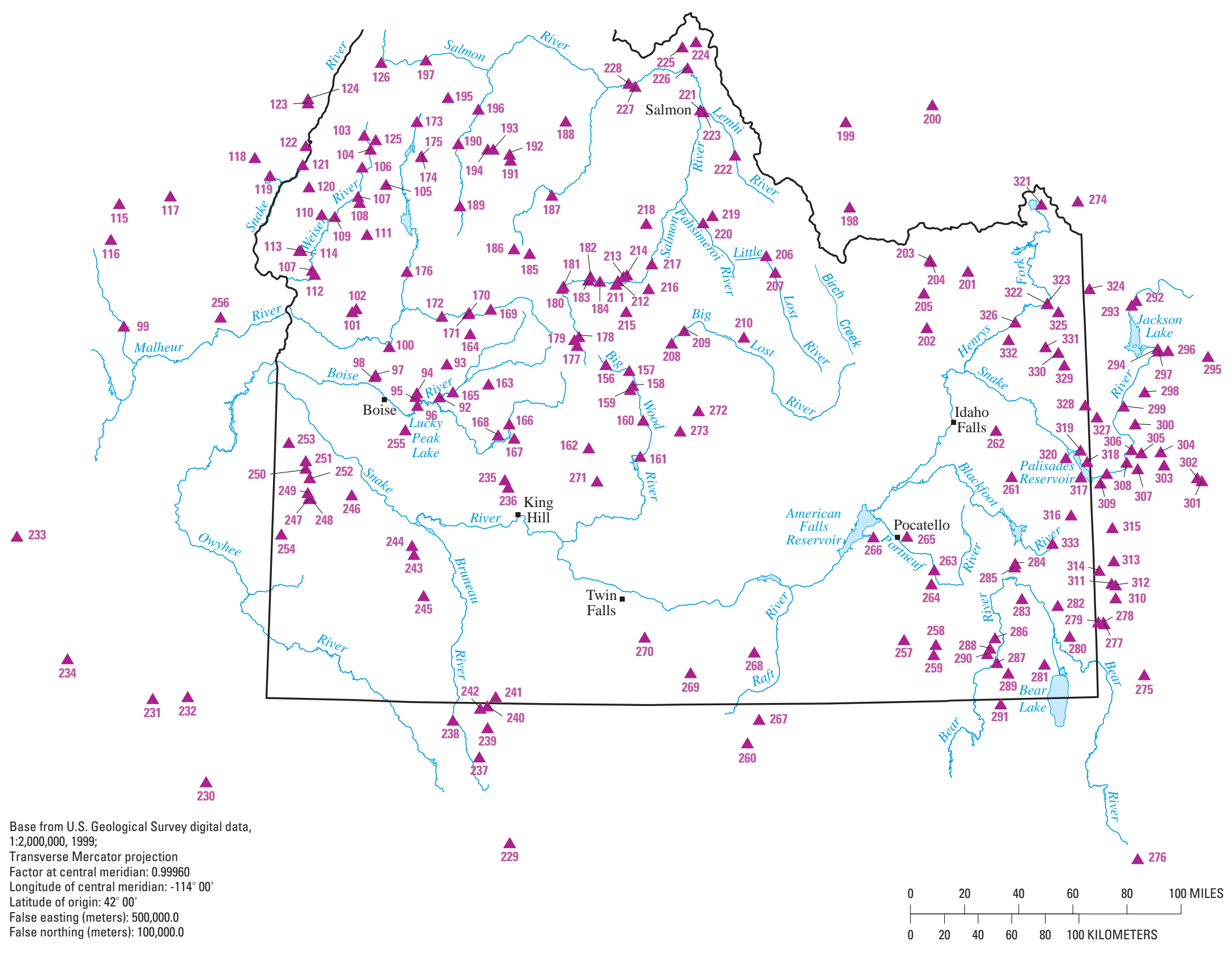

Figure 1. Locations of streamflow-gaging stations in Idaho and bordering States used in regional regression analysis. 
these equations was 2 years and did not include the 2.33-year recurrence interval, which is also a standard output from the U.S. Geological Survey (USGS) floodfrequency program.

In 2003, using data obtained for Berenbrock's 2002 study, the USGS conducted a study in cooperation with the USFS to develop additional regional regression equations that can be used to estimate bankfull flows. The equations developed in this study will provide more accurate estimates of bankfull flows for ungaged streams in Idaho.

\section{Purpose and Scope}

This report documents the development of regression equations used for estimating the magnitude of peak flows with recurrence intervals of 1.5 and 2.33 years. Equations for peak flows with a 2-year recurrence interval estimated previously by Berenbrock (2002) also are presented. Data from Berenbrock's study of 333 gaging stations with at least 10 years of record through water year 1997 were used to develop the regression equations for this study. The equations are in the same format and were developed for the same regions as those provided in Berenbrock's study. Standard errors of estimates are included to help predict the reliability and accuracy of each equation.

\section{Description of Study Area}

The study area (fig. 1) is the entire State of Idaho and areas of adjacent States where particular drainage basins cross over State boundaries. The adjacent States partially included in the study area are Washington, Oregon, Nevada, Utah, Wyoming, and Montana. The northern and central parts of the area comprise mainly rugged, mountainous terrain; broad plains and mildly sloping valleys and hills predominate in the south. Geologic features across the study area consist of sedimentary, igneous, and metamorphic rocks ranging in age from Precambrian to Holocene (Bond, 1978). The granitic Idaho batholith is the major structural feature in the central part of the study area, and basalt covers much of the southern and western parts (Ross and Savage, 1967).

Most precipitation in the study area results from storms moving inland from the Pacific Ocean. The amount of precipitation varies widely and is greatly affected by topography. Precipitation ranges from less than $10 \mathrm{in} / \mathrm{yr}$ on the Snake River Plain in south-central Idaho to 60 to $70 \mathrm{in} / \mathrm{yr}$ in the central mountains of Idaho (Molnau, 1995). Precipitation is greatest during the winter and the most significant amounts are a direct result of orographic effects. Spring and summer thunderstorms in the southern part of the study area sometimes produce large amounts of precipitation. Resulting streamflow varies geographically and seasonally and can be affected by land use and vegetation. During much of the year, streamflow in most unregulated streams in the study area is minimal base flow; during April, May, June, and July, streamflow is significantly higher, primarily as a result of snowmelt. Occasionally during the winter months, large frontal systems carrying warmer air release moisture as rain on the snowpack and frozen ground, which results in rapid snowmelt and high runoff rates, particularly at elevations less than 6,000 ft above sea level (National Oceanic and Atmospheric Administration, 1971).

\section{Acknowledgments}

The authors recognize the hard work and dedication of the many USGS hydrologic technicians and hydrologists in collecting, processing, and storing the peak-flow data necessary for the completion of this report. Also, the authors appreciate the assistance of the many Federal, State, and local agencies that financially support operations of streamflow-gaging stations throughout Idaho where peak-flow data are collected.

\section{PREVIOUS INVESTIGATIONS}

Emmett (1975) developed equations that related bankfull discharge to other channel-geometry and flow characteristics in the upper Salmon River Basin in south-central Idaho. The main assumption in the study was that river channels are shaped by the dominant flow, which was defined as the bankfull flow. Only equations for the 1.5-year recurrence interval flood (assumed to be the bankfull flow) were developed during Emmett's study.

Harenberg (1980) developed several sets of regression equations for Idaho on the basis of channelgeometry and basin characteristics. He developed equations to predict the 1.25-, 2-, 5-, 10-, 25-, 50-, and 100 -year peak flows at ungaged sites. The characteristics in the final equations were bankfull width, drainage 
area, and 24-hour rainfall intensity for the 2-year recurrence interval. He used fewer gaging stations than previous flood-frequency studies because channel-geometry characteristics could not be determined at every gaging station. He demonstrated that standard errors were smaller when channel-geometry variables were included with basin characteristics in regression equations, but standard errors in his study were 20 to 30 percent larger than those in Berenbrock's (2002) study; Berenbrock's dataset was approximately twice as large as Harenberg's. Regional regression equations for estimating streamflow statistics in the Western United States were developed by Hedman and Osterkamp (1982). The regression equations were developed for various streamflow statistics using channel geometry. However, data from only three gages in Idaho (located on tributaries to the Snake River) were used in their analysis.

\section{COMPILATION OF DATA}

All data used to develop regression equations for estimating peak flows with recurrence intervals of 1.5 and 2.33 years were obtained from the report by Berenbrock (2002). These data consisted of basin and climatic characteristics and peak-flow records for each of the relevant gaging stations. In addition, the regional boundaries determined by Berenbrock (2002) also were used in this study.

\section{Basin and Climatic Characteristics}

Use of the same independent variables in each of the peak-flow equations for a specific region ensures that the correlation structure among the streamflow statistics for each region is preserved so that estimates of the statistics are stable and consistent (Haan, 1977). For this reason, equations developed in this study use the same independent variables (basin and climatic characteristics) as the equations developed by Berenbrock (2002) for each region. Thus, the same seven basin and climatic characteristics used by Berenbrockdrainage area (DA), mean basin elevation (E), forested area $(\mathrm{F})$, mean annual precipitation $(\mathrm{P})$, basin slope (BS), north-facing slopes greater than 30 percent (NF30), and slopes greater than 30 percent (S30)also were used in this analysis. Data sources used to obtain these characteristics are listed in table 1, general descriptions of the seven characteristics used in the final equations are listed in table 2 , and basin and climatic characteristic values obtained for each gaging station are listed in appendix A (back of report; table 4

Table 1. Selected data sources used to obtain basin and climatic characteristics for regional regression analysis

[Multiply meter by 3.281 to obtain foot; multiply kilometer $(\mathrm{km})$ by 0.6214 to obtain mile]

\begin{tabular}{c|c}
\hline \multicolumn{1}{c|}{ Dataset name } & \multicolumn{1}{c}{ Source description } \\
\hline National Elevation Dataset (NED) & $\begin{array}{c}\text { Basin characteristics were calculated using 30-meter resolution digital elevation data; } \\
\text { http://gisdata.usgs.gov/ned/default.asp }\end{array}$ \\
\hline $\begin{array}{c}\text { National Elevation Dataset } \\
\text { Hydrologic Derivatives (NED-H) }\end{array}$ & $\begin{array}{c}\text { Hydrologic derivatives of NED data were developed using procedures similar to those in Stage 1 } \\
\text { processing, using a custom projection for Idaho; } \\
\text { http://edcnts12.cr.usgs.gov/ned-h/about/Stage1.html }\end{array}$ \\
\hline & $\begin{array}{l}\text { Vogelmann, J.E., Sohl, T.L., Campbell, P.V., and Shaw, D.M., 1998, Regional land cover } \\
\text { characterization using Landsat Thematic Mapper data and ancillary data sources: Environmental } \\
\text { Monitoring and Assessment, v. 51, p. 415-428 } \\
\text { (http://edcwww.cr.usgs.gov/programs/lccp) }\end{array}$ \\
\hline $\begin{array}{c}\text { National Land Cover Dataset (NLCD) } \\
\text { Idaho map of mean annual } \\
\text { precipitation }{ }^{1}\end{array}$ & $\begin{array}{c}\text { Molnau, M., 1995, Mean annual precipitation, 1961-1990, Idaho: Moscow, University of Idaho, } \\
\text { Agricultural Engineering Department, State Climate Program, scale 1:1,000,000 } \\
\text { (http://snow.ag.uidaho.edu/Climate/reports.html) }\end{array}$ \\
\hline $\begin{array}{c}\text { Western United States average } \\
\text { monthly or annual precipitation }{ }^{2}\end{array}$ & $\begin{array}{c}\text { Daly, C., and Taylor, G., 1998, Western United States average monthly or annual precipitation, } \\
\text { 1961-90, Oregon: Portland, Water and Climate Center of the Natural Resources Conservation } \\
\text { Service, grid-cell resolution 4 km (http://www.ocs.orst.edu/prism/prism_new.html) }\end{array}$ \\
\hline $\begin{array}{l}{ }^{1} \text { Used for areas in Idaho. } \\
\text { Used for areas outside of Idaho. }\end{array}$
\end{tabular}


Table 2. Description of selected basin and climatic characteristics used in the final predictive equations

[Multiply meter by 3.281 to obtain foot; multiply kilometer $(\mathrm{km})$ by 0.6214 to obtain mile]

\begin{tabular}{l|l}
\hline \multicolumn{1}{c|}{ Characteristic } & \multicolumn{1}{c}{ Description } \\
\hline Drainage area (DA) & $\begin{array}{l}\text { Drainage area of the basin that contributes surface runoff, in square miles; estimated using } \\
\text { Arc/Info Grid with 30-meter resolution digital elevation models (DEMs) }\end{array}$ \\
\hline Mean basin elevation (E) & $\begin{array}{l}\text { Mean elevation of the basin, in feet above sea level; estimated using Arc/Info Grid and } \\
\text { averaging elevations using 30-meter resolution DEMs }\end{array}$ \\
\hline Forested area (F) & $\begin{array}{l}\text { Area of the basin containing forest, in percent of total drainage area; estimated using } \\
\text { Arc/Info Grid with a 37-meter resolution land cover grid }\end{array}$ \\
\hline Mean annual precipitation (P) & $\begin{array}{l}\text { Mean annual precipitation over the entire drainage area, in inches; estimated using Arc/Info } \\
\text { Grid with a combination of 500-meter (within Idaho) and 4-km (outside of Idaho) resolution } \\
\text { precipitation grids }\end{array}$ \\
\hline Basin slope (BS) & $\begin{array}{l}\text { Average slope of the basin, in percent; estimated using the "average maximum technique" } \\
\text { in Arc/Info Grid with 30-meter resolution DEMs }\end{array}$ \\
\hline $\begin{array}{l}\text { North-facing slopes greater than } \\
30 \text { percent (NF30) }\end{array}$ & $\begin{array}{l}\text { Area of north-facing slopes with slopes greater than 30 percent, in percent of drainage area; } \\
\text { estimated using the "average maximum technique" in Arc/Info Grid with 30-meter } \\
\text { resolution DEMs }\end{array}$ \\
\hline Slopes greater than 30 percent (S30) & $\begin{array}{l}\text { Area with slopes greater than 30 percent, in percent of drainage area; estimated using the } \\
\text { "average maximum technique" in Arc/Info Grid with 30-meter resolution DEMs }\end{array}$ \\
\hline
\end{tabular}

in Berenbrock, 2002). Detailed information concerning how these values were obtained can be found in Berenbrock's report (2002, p. 5).

\section{Peak-Flow Data}

Peak-flow data from 333 gaging stations (fig. 1; appendix B, back of report) with at least 10 years of record through water year 1997 (Berenbrock, 2002) were used in this analysis. These data represented naturally occurring flows that were not affected by regulation or large irrigation diversions. Most data were from continuous-record sites where stage is recorded at a fixed interval, typically ranging from 15 to 60 minutes. Some data were collected at crest-stage sites where only the peak, or highest stage that occurs between site visits (usually several months), is recorded.

\section{Determination of Regions}

Because of the need for stable and consistent estimates at a specific site, the same region boundaries defined by Berenbrock (2002) also were used in this analysis. This resulted in nine separate study regions and one undefined region (fig. 2). The undefined region is almost entirely made up of the area commonly referred to as the eastern Snake River Plain. This area includes several dams, major irrigation diversions, springs with extremely large discharges, and channel bottoms with very high infiltration rates. Because flows influenced by these conditions cannot be characterized by a regional regression approach, this area was not included in the analysis. More detailed information on how the regional boundaries were determined can be found in previous reports by Berenbrock (2002, p. 8) and Hortness and Berenbrock (2001, p. 6).

\section{ESTIMATION METHODS}

Regional regression equations that can be used to estimate the magnitude of peak flows with recurrence intervals of 1.5 and 2.33 years at ungaged sites were developed during this study. Equations for estimating peak flows with a recurrence interval of 2 years that were developed by Berenbrock (2002) also are included for comparison.

Regression techniques were used to define a set of predictive equations that related peak flows with recur- 


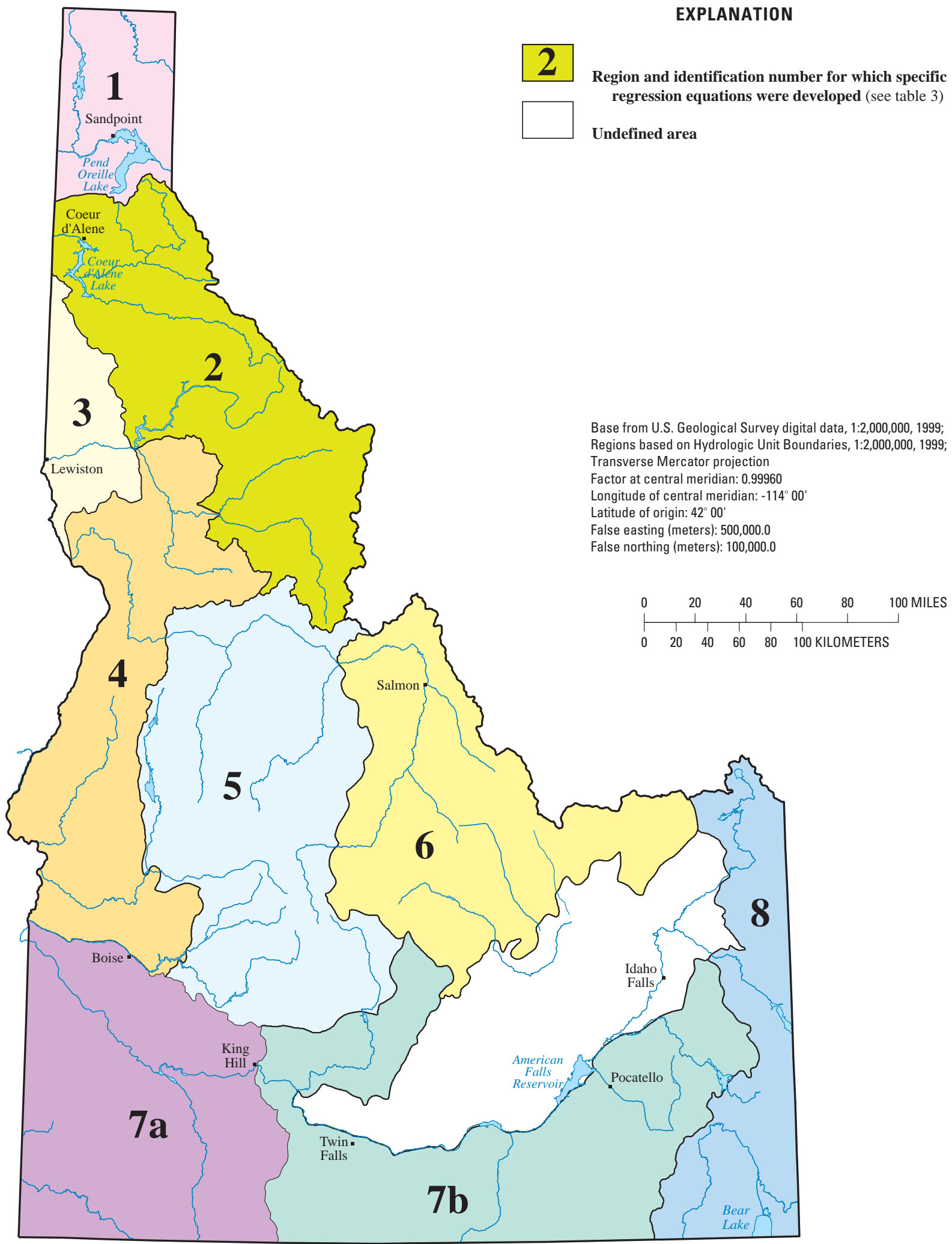

Figure 2. Locations of regions in Idaho used in regional regression analysis. 


\section{Estimating the Magnitude of Bankfull Flows for Streams in Idaho}

rence intervals of 1.5 and 2.33 years to selected basin and climatic characteristics for each region in Idaho. The initial step involved performing a flood-frequency analysis of the peak-flow data for each gaging station to determine the peak-flow values for selected recurrence intervals. Next, all the peak-flow, basin, and climatic characteristic data were transformed to base-10 logarithms to obtain a linear regression model and to achieve equal variance about the regression line. Equal variance about the regression line satisfies the basic assumption that the distribution of errors is normal and constant throughout the range (Riggs, 1968). Prior to the transformation, a value of 1 was added to data that were a measure of percentage (such as forest cover) to ensure that no 0 values, which cannot be transformed, were present. Also, mean basin elevation (E) values were divided by 1,000 to allow for more convenient coefficients in the final equations.

Finally, using the same explanatory variables for each region as defined by Berenbrock (2002), generalized least-squares (GLS) regression techniques were used to calculate the final coefficients and measures of accuracy for the regression equations for each region. GLS techniques (Stedinger and Tasker, 1985) can account for correlation between sites, differences in record lengths, and variability of peak flows at gaged sites. These factors are accounted for by assigning different weights to each observation of the peak flow on the basis of its contribution to the total variance of the sample flow statistic. A more detailed discussion of how GLS accounts these factors can be found in Berenbrock's (2002, p. 13) report.

\section{RESULTS}

Drainage area (DA), mean basin elevation (E), mean annual precipitation $(\mathrm{P})$, forest cover $(\mathrm{F})$, northfacing slopes greater than 30 percent (NF30), basin slope (BS), and slopes greater than 30 percent (S30) were the explanatory variables that were included in regression equations. No equation included more than three explanatory variables, and region $7 \mathrm{~b}$ was the only region that included only one explanatory variable (DA).

The standard error of the regression model and the average standard error of prediction also are listed in table 3. The standard error of the regression analysis (model) is a measure of how well the regression model fits the data used to construct it. This error term also is often referred to as the standard error of estimate. The average standard error of prediction is the sum of two components - model error plus sampling errorwhich results from estimating model parameters from samples of the population. The model error is a characteristic of the model and is a constant for all sites. The sampling error for a given site, however, depends on the values of the explanatory variables used to develop the peak-flow estimate at that site and, thus, varies from site to site. The standard error of prediction provides a better overall measure of a model's predictive reliability than does the model error. A more rigorous mathematical description of these errors and how to convert them from logarithms (base-10 units) to percent errors is given in a report by Pope and Tasker (1999, p. 12).

Standard errors of the model were different for each region and for each recurrence interval (table 3 ). The largest and smallest average standard errors of the model were +150 and -60.1 percent (region $7 b, Q 1.5$ ) and +42.9 and -30.0 percent (region 5, Q2.33), respectively. Similarly, the largest and smallest average standard errors of prediction were +165 and -62.2 percent (region 7b, Q1.5) and +45.9 and -31.5 percent (region 5 , Q2.33), respectively (table 3). Overall, region 5 equations would be expected to have the smallest error and region $7 \mathrm{~b}$ equations would be expected to have the largest error. The larger errors associated with the region $7 \mathrm{~b}$ equations likely result from use of a small number of gaging stations (17) in a region of more diverse geology, which can have unknown effects on small peak flows.

\section{LIMITATIONS}

The average standard errors of prediction given in table 3 represent the general measure of how well the regional regression equations will estimate peak flows when they are applied to ungaged sites. The accuracy of the equations will be reduced if the values of explanatory variables are outside the range of the values used to develop the equations. The magnitude of this reduction in accuracy is unknown. Standard errors of prediction vary from site to site, depending on the values of the explanatory variables for each site. The standard errors of prediction will be smaller for sites where values of the explanatory variables are near the mean of their range. If the value of an explanatory variable used 
Table 3. Predictive regression equations and their accuracy in estimating peak flows for ungaged sites on unregulated and undiverted streams in Idaho

[Q, peak flow, in cubic feet per second; DA, drainage area, in square miles; E, mean basin elevation, in feet; F, percentage of forest cover in the basin; P, mean annual precipitation, in inches; NF30, percentage of north-facing slopes greater than 30 percent; S30, percentage of slopes greater than 30 percent; and BS, average basin slope, in percent]

\begin{tabular}{|c|c|c|}
\hline Peak-flow regression equations for given recurrence interval & $\begin{array}{l}\text { Standard error of model } \\
\text { (percent) }\end{array}$ & $\begin{array}{l}\text { Standard error } \\
\text { of prediction } \\
\text { (percent) }\end{array}$ \\
\hline \multicolumn{3}{|l|}{ Region 1 (Data were based on 21 gaging stations) } \\
\hline $\begin{array}{l}\mathrm{Q}_{1.5}=0.748 \mathrm{DA}^{0.802}(\mathrm{E} / 1,000)^{3.28}(\mathrm{~F}+1)^{-0.283} \\
{ }^{1} \mathrm{Q}_{2}=2.52 \mathrm{DA}^{0.775}(\mathrm{E} / 1,000)^{3.32}(\mathrm{~F}+1)^{-0.504} \\
\mathrm{Q}_{2.33}=3.90 \mathrm{DA}^{0.764}(\mathrm{E} / 1,000)^{3.32}(\mathrm{~F}+1)^{-0.577}\end{array}$ & $\begin{array}{l}+76.7 \text { to }-43.4 \\
+69.0 \text { to }-40.8 \\
+65.1 \text { to }-39.4\end{array}$ & $\begin{array}{l}+87.1 \text { to }-46.5 \\
+78.4 \text { to }-43.9 \\
+73.9 \text { to }-42.5\end{array}$ \\
\hline \multicolumn{3}{|l|}{ Region 2 (Data were based on $\mathbf{4 4}$ gaging stations) } \\
\hline $\begin{array}{l}\mathrm{Q}_{1.5}=0.508 \mathrm{DA}^{0.901}(\mathrm{E} / 1,000)^{0.132} \mathrm{P}^{0.926} \\
{ }^{2} \mathrm{Q}_{2}=0.742 \mathrm{DA}^{0.897} \mathrm{P}^{0.935} \\
\mathrm{Q}_{2.33}=0.863 \mathrm{DA}^{0.894}(\mathrm{E} / 1,000)^{-0.0587} \mathrm{P}^{0.941}\end{array}$ & $\begin{array}{l}+61.4 \text { to }-38.1 \\
+60.2 \text { to }-37.6 \\
+59.9 \text { to }-37.4\end{array}$ & $\begin{array}{l}+65.5 \text { to }-39.6 \\
+64.2 \text { to }-39.1 \\
+63.9 \text { to }-39.0\end{array}$ \\
\hline \multicolumn{3}{|l|}{ Region 3 (Data were based on 26 gaging stations) } \\
\hline $\begin{array}{l}\mathrm{Q}_{1.5}=12.6 \mathrm{DA}^{0.879}(\mathrm{E} / 1,000)^{-0.161} \\
{ }^{1} \mathrm{Q}_{2}=26.3 \mathrm{DA}^{0.864}(\mathrm{E} / 1,000)^{-0.502} \\
\mathrm{Q}_{2.33}=45.0 \mathrm{DA}^{0.856}(\mathrm{E} / 1,000)^{-0.849}\end{array}$ & $\begin{array}{l}+98.1 \text { to }-49.5 \\
+78.3 \text { to }-43.9 \\
+70.5 \text { to }-41.3\end{array}$ & $\begin{array}{l}+108 \text { to }-52.0 \\
+86.4 \text { to }-46.4 \\
+77.9 \text { to }-43.8\end{array}$ \\
\hline \multicolumn{3}{|l|}{ Region 4 (Data were based on 60 gaging stations) } \\
\hline $\begin{array}{l}\mathrm{Q}_{1.5}=9.49 \mathrm{DA}^{0.903}(\mathrm{E} / 1,000)^{0.055} \\
{ }^{1} \mathrm{Q}_{2}=16.3 \mathrm{DA}^{0.893}(\mathrm{E} / 1,000)^{-0.121} \\
\mathrm{Q}_{2.33}=20.3 \mathrm{DA}^{0.890}(\mathrm{E} / 1,000)^{-0.193}\end{array}$ & $\begin{array}{l}+89.2 \text { to }-47.2 \\
+80.5 \text { to }-44.6 \\
+77.2 \text { to }-43.6\end{array}$ & $\begin{array}{l}+92.6 \text { to }-48.1 \\
+83.5 \text { to }-45.5 \\
+80.1 \text { to }-44.5\end{array}$ \\
\hline \multicolumn{3}{|l|}{ Region 5 (Data were based on 46 gaging stations) } \\
\hline $\begin{array}{l}\mathrm{Q}_{1.5}=0.0157 \mathrm{DA}^{1.01} \mathrm{P}^{2.34}(\mathrm{NF} 30+1)^{-0.696} \\
{ }^{1} \mathrm{Q}_{2}=0.0297 \mathrm{DA}^{0.995} \mathrm{P}^{2.20}(\mathrm{NF} 30+1)^{-0.664} \\
\mathrm{Q}_{2.33}=0.0388 \mathrm{DA}^{0.990} \mathrm{P}^{2.13}(\mathrm{NF} 30+1)^{-0.651}\end{array}$ & $\begin{array}{l}+45.6 \text { to }-31.3 \\
+43.6 \text { to }-30.4 \\
+42.9 \text { to }-30.0\end{array}$ & $\begin{array}{l}+48.9 \text { to }-32.9 \\
+46.7 \text { to }-31.8 \\
+45.9 \text { to }-31.5\end{array}$ \\
\hline \multicolumn{3}{|l|}{ Region 6 (Data were based on 31 gaging stations) } \\
\hline $\begin{array}{l}{ }^{3} \mathrm{Q}_{1.5}=1.41 \cdot 10^{-4} \mathrm{DA}^{0.904} \mathrm{P}^{3.25} \\
{ }^{1} \mathrm{Q}_{2}=2.58 \cdot 10^{-4} \mathrm{DA}^{0.893} \mathrm{P}^{3.15} \\
\mathrm{Q}_{2.33}=4.16 \cdot 10^{-4} \mathrm{DA}^{0.882} \mathrm{P}^{3.04}\end{array}$ & $\begin{array}{l}+72.4 \text { to }-42.0 \\
+71.2 \text { to }-41.6 \\
+68.9 \text { to }-40.8\end{array}$ & $\begin{array}{l}+78.1 \text { to }-43.8 \\
+76.5 \text { to }-43.4 \\
+74.2 \text { to }-43.6\end{array}$ \\
\hline \multicolumn{3}{|l|}{ Region 7a (Data were based on 28 gaging stations) } \\
\hline $\begin{array}{l}{ }^{4} \mathrm{Q}_{1.5}=0.699 \mathrm{DA}^{0.758}(\mathrm{E} / 1,000)^{1.213} \\
{ }^{1} \mathrm{Q}_{2}=2.28 \mathrm{DA}^{0.759}(\mathrm{E} / 1,000)^{0.769} \\
\mathrm{Q}_{2.33}=3.99 \mathrm{DA}^{0.760}(\mathrm{E} / 1,000)^{0.544}\end{array}$ & $\begin{array}{l}+86.9 \text { to }-46.5 \\
+74.8 \text { to }-42.8 \\
+71.1 \text { to }-41.6\end{array}$ & $\begin{array}{l}+95.6 \text { to }-48.9 \\
+82.3 \text { to }-45.2 \\
+78.3 \text { to }-43.9\end{array}$ \\
\hline \multicolumn{3}{|l|}{ Region 7b (Data were based on 17 gaging stations) } \\
\hline $\begin{array}{l}\mathrm{Q}_{1.5}=7.82 \mathrm{DA}^{0.606} \\
{ }^{1} \mathrm{Q}_{2}=10.2 \mathrm{DA}^{0.611} \\
\mathrm{Q}_{2.33}=11.4 \mathrm{DA}^{0.613}\end{array}$ & $\begin{array}{l}+150 \text { to }-60.1 \\
+131 \text { to }-56.6 \\
+123 \text { to }-55.1\end{array}$ & $\begin{array}{l}+165 \text { to }-62.2 \\
+143 \text { to }-58.8 \\
+134 \text { to }-57.3\end{array}$ \\
\hline \multicolumn{3}{|l|}{ Region 8 (Data were based on 60 gaging stations) } \\
\hline $\begin{array}{l}\mathrm{Q}_{1.5}=1.23 \mathrm{DA}^{0.958} \mathrm{BS}^{0.984}(\mathrm{~S} 30+1)^{-0.421} \\
{ }^{1} \mathrm{Q}_{2}=1.49 \mathrm{DA}^{0.942} \mathrm{BS}^{1.15}(\mathrm{~S} 30+1)^{-0.563} \\
\mathrm{Q}_{2.33}=1.59 \mathrm{DA}^{0.936} \mathrm{BS}^{1.23}(\mathrm{~S} 30+1)^{-0.623}\end{array}$ & $\begin{array}{l}+88.7 \text { to }-47.0 \\
+82.9 \text { to }-45.3 \\
+81.0 \text { to }-44.7\end{array}$ & $\begin{array}{l}+93.0 \text { to }-48.2 \\
+86.9 \text { to }-46.5 \\
+84.8 \text { to }-45.9\end{array}$ \\
\hline
\end{tabular}

\footnotetext{
${ }^{1}$ From Berenbrock (2002, table 7, p. 16-18).

${ }^{2}$ Exponent for $(\mathrm{E} / 1,000)$ is zero which is equivalent to multiplying by one; $(\mathrm{E} / 1,000)^{0}=1$. analysis.

Data were based on 30 gaging stations. The 1.5 -year peak flow was below the base flow for gaging station 13301800 , and thus was excluded from the

${ }^{4}$ Data were based on 27 gaging stations. The 1.5-year peak flow was below the base flow for gaging station 13172200, and thus was excluded from the analysis.
} 


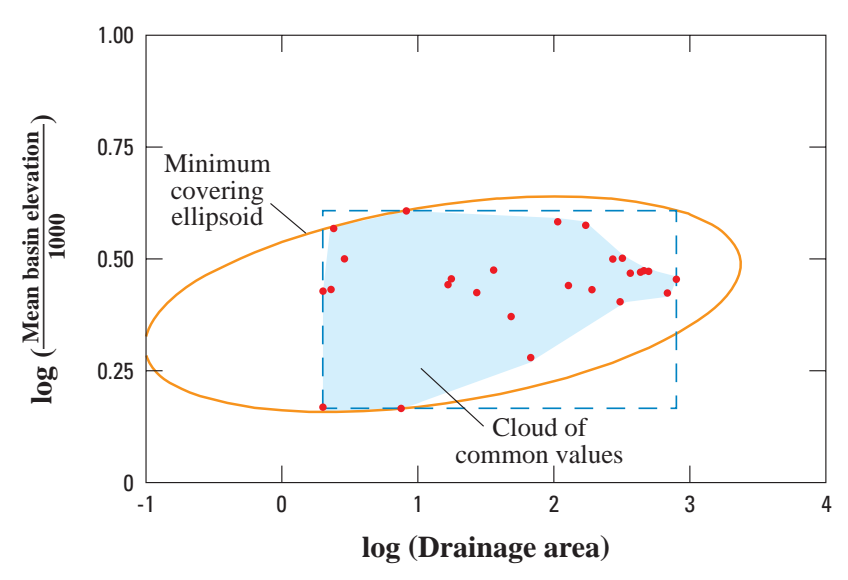

Figure 3. Joint distribution of drainage area and mean basin elevation, and minimum covering ellipsoid for gaged sites in region 3 , Idaho.

in the regression equations is near its extreme (maximum or minimum, appendix A), the equations might result in unreliable and erroneous estimates. For example, figure 3 shows a "cloud of common values" for the two explanatory variables used in regression equations for region 3. If the maximum value for drainage area and the minimum value for mean basin elevation were used, this combination would plot outside the cloud of common values and, thus, any equations used might result in unreliable estimates.

Generating basin characteristic values using source datasets or methods other than those described in this study also will result in estimates of unknown reliability. The standard errors for each equation are applicable only if the datasets presented in table 1 and methods described in table 2 are used to obtain the required basin characteristics.

The regression equations are not applicable for streams that exhibit significant gains and (or) losses as a result of flow from springs or seepage through highly permeable streambeds. The equations also are not applicable for streams affected by irrigation diversions or large dams that regulate streamflow. The Boise River downstream from Lucky Peak Lake, the Clearwater River downstream from Dworshak Reservoir, and the entire Snake River in Idaho are examples of stream reaches within the study area for which the regional regression equations are not applicable.

Finally, the regional regression equations might not be reliable for sites in heavily urbanized basins. Techniques for estimating peak flows for urban streams are presented in a report by Sauer and others (1983).

\section{APPLICATION OF METHODS}

In the subsequent paragraphs, specific examples are given for calculating peak flows. The first example addresses the situation where the drainage area for an ungaged site is located completely within one region. The second example addresses the situation where the drainage area of the specified site encompasses parts of two separate regions. It is important to note that the coefficients and exponents in the predictive equations are rounded to three significant figures. Thus, the final peak-flow estimate derived from these equations will have an accuracy no greater than to three significant figures.

\section{Example 1}

A 1.5-year peak-flow estimate for an ungaged site in region 5 is needed. The required basin characteristics for region 5 regional regression equations were determined to be the following: $\mathrm{DA}=480.5 \mathrm{mi}^{2}$; $\mathrm{P}=28.33$ in.; and NF30 $=21.5$ percent. Then

$\mathrm{Q} 1.5=0.0157 \mathrm{DA}^{1.01} \mathrm{P}^{2.34}(\mathrm{NF} 30+1)^{-0.696}$

$\mathrm{Q} 1.5=0.0157(480.5)^{1.01}(28.33)^{2.34}(21.5+1)^{-0.696}$ $\mathrm{Q} 1.5=2,300 \mathrm{ft}^{3} / \mathrm{s}$

On the basis of the range of the average standard errors of prediction given in table 3 , about 67 percent of all estimates at this site will be between 1,580 and $3,360 \mathrm{ft}^{3} / \mathrm{s}(-31.5$ to +45.9 percent $)$. Put another way, there is about a 67 -percent certainty that the "true" value of Q1.5 is between 1,580 and 3,360 $\mathrm{ft}^{3} / \mathrm{s}$. Instead of calculating these equations (table 3 ) manually, a computer program explained in the section titled "Computer Program for Regional Regression Equations" can be used. This computer program also calculates the error of prediction and the 90-percent confidence interval for individual estimates for each recurrence interval and for each region.

\section{Example 2}

A 1.5-year peak-flow estimate is needed for an ungaged site in region 4 with a drainage basin encompassing parts of regions 4 and 5 . The procedure is similar to that given in example 1, except the regional regression equations need to be solved for each of the associated regions and the results averaged or appor- 
tioned according to the fraction of the contributing drainage area that is in each region (Sando, 1998).

The required basin characteristics for region 4 and 5 equations were determined to be the following: $\mathrm{DA}=853.0 \mathrm{mi}^{2} ; \mathrm{P}=35.4 \mathrm{in} . ; \mathrm{E}=5,125.6 \mathrm{ft}$; and $\mathrm{NF} 30=23.6$ percent. The part of the drainage area in region 4 is $622.0 \mathrm{mi}^{2}$ and the part in region 5 is $231.0 \mathrm{mi}^{2}$.

\section{(1) REGION 4 EQUATION}

$\mathrm{Q} 1.5=9.49 \mathrm{DA}^{0.903}(\mathrm{E} / 1,000)^{-0.055}$

$\mathrm{Q} 1.5=9.49(853.0)^{0.903}(5,125.6 / 1,000)^{-0.055}$

$\mathrm{Q} 1.5=3,845 \mathrm{ft}^{3} / \mathrm{s}$

\section{(2) REGION 5 EQUATION}

$\mathrm{Q} 1.5=0.0157 \mathrm{DA}^{1.01} \mathrm{P}^{2.34}(\mathrm{NF} 30+1)^{-0.696}$

$\mathrm{Q} 1.5=0.0157(853.0)^{1.01}(35.4)^{2.34}(23.6+1)^{-0.696}$

$\mathrm{Q} 1.5=6,497 \mathrm{ft}^{3} / \mathrm{s}$

\section{(3) AREA-WEIGHTED AVERAGE OF THE 1.5-YEAR PEAK} FLOWS

$$
Q_{u}=Q_{x_{n}}\left(\frac{D A_{x_{n}}}{D A}\right)+Q_{x_{n}}\left(\frac{D A_{x_{n}}}{D A}\right)
$$

where

$\mathrm{Q}_{\mathrm{u}}$ is peak flow for the selected flood frequency for the ungaged site,

$\mathrm{Q}_{\mathrm{X}}$ is estimated peak flow using the equation for the selected region,

$\mathrm{DA}_{\mathrm{x}}$ is drainage area for the selected region,

DA is total drainage area upstream from the ungaged site, and

$\mathrm{x}_{\mathrm{n}}$ is selected region where $\mathrm{n}=1$ through 9 .

$\mathrm{Q} 1.5=3,845(622.0 / 853.0)+6,497(231.0 / 853.0)$

$\mathrm{Q} 1.5=4,560 \mathrm{ft}^{3} / \mathrm{s}$

The regional regression equation computer program also can be used to estimate the peak-flow values in this example. The program would need to be executed twice, once for region 4 and once for region 5 . Then, the average value would need to be estimated manually by weighting according to drainage area (area-weighted average), as shown in equation 4.

\section{COMPUTER PROGRAM FOR REGIONAL REGRESSION EQUATIONS}

As part of the previous peak-flow study by Berenbrock (2002), a computer program was adapted to calculate peak flows using regional regression equations. The program also calculates the associated site-specific errors of prediction for ungaged sites. Regression equations for 1.5 and 2.33 recurrence interval peak flows developed during this study (table 3 ) have been added to this program. The computer software package includes an executable program file and other supporting files. The software package and instructions for downloading, installing, and executing the program are available from the Idaho District home page on the World Wide Web at http://idaho.usgs.gov/PDF/ wri024170/program.html The executable program idregeq.exe will calculate estimated peak flows for the regional regression equations presented in table 3 of this report and in table 7 of Berenbrock's (2002) report. This program must be executed in a disk operating system (DOS) and the user will be prompted to input data for ungaged sites.

The regional regression equations can be calculated manually, but the program allows more convenient and efficient calculation of the errors of prediction. The errors of prediction for ungaged sites are calculated by matrix algebra using the weighted matrix $\left(\mathrm{X}^{\mathrm{T}} \Lambda^{-1} \mathrm{X}\right)^{-1}$ obtained from GLS analysis. Further explanation for computing the error of prediction is given in a report by Hodgkins (1999), and the $\left(\mathrm{X}^{\mathrm{T}} \Lambda^{-1} \mathrm{X}\right)^{-1}$ matrices for each recurrence interval and region are shown in appendix $\mathrm{C}$ of this report (back of report) and in table 9 of Berenbrock's (2002) report.

To execute the regional regression program, enter the program's name (idregeq.exe) in a DOS window. The program will ask for the name of an output file to save program results, an identifier (name and/or number) of the ungaged site, the region number where the ungaged site is located, and the value for each explanatory variable used in the region's regional regression equations. Results will be displayed on the screen, and all program results will be saved in a single output file no matter how many times the program repeats. Results from each program execution comprise calculated peak flows, site-specific standard errors of prediction (SE), and 90-percent confidence intervals for the estimates. A more detailed discussion explaining the use of the 


\section{Estimating the Magnitude of Bankfull Flows for Streams in Idaho}

regional regression program, how to interpret the results, and cautions to be aware of can be found in the previous report by Berenbrock (2002, p. 22).

\section{SUMMARY}

Recent increased interest in the biological, geomorphic, and environmental effects of varying river flows has highlighted the need for information regarding annual peak flows with relatively short recurrence intervals. Peak flows with recurrence intervals between 1.5 and 2.33 years, often referred to as bankfull flows, are important for mobilization of streambed sediments (cleansing), maintenance of width and depth features of the channel, and maintenance of riparian vegetation. Currently, this information is available only for gaged sites that have at least 10 years of annual peak-flow record. Berenbrock (2002) developed regional peakflow regression equations for ungaged streams in Idaho; however, the minimum recurrence interval for these equations was 2 years and did not include the 2.33-year recurrence interval. Recognizing the need for this additional information, the U.S. Geological Survey, in cooperation with the U.S. Forest Service, conducted a study to develop additional regional regression equations that can be used to estimate bankfull flows.

Basin and climatic characteristics, peak-flow records, and regional boundaries presented by Berenbrock (2002) were used in this study to develop regional regression equations for estimating peak flows with recurrence intervals of 1.5 and 2.33 years. Basin and climatic characteristics and peak-flow records were included for 333 gaging stations with at least 10 years of record through water year 1997. The State was divided into 10 regions, which included one undefined region in the area of the eastern Snake River Plain.

Because of the need for stable and consistent estimates of peak flows in each region, the same explanatory variables used by Berenbrock (2002) also were used in this study for each region. Generalized leastsquares regression techniques then were used to calculate the final coefficients and measures of accuracy for the regression equations for each region. Average standard errors of the model ranged from +150 to -60.1 percent, and average standard errors of prediction ranged from +165 to -62.2 percent. As the recurrence intervals increased, the magnitude and the range between the errors decreased. The ranges of standard errors of the model and standard errors of prediction were narrowest for region 5 .

The estimating equations might not yield reliable results for sites with basin characteristic values outside of the range of values used to develop the equations. The equations are not applicable for regulated streams or those affected by significant gains and (or) losses owing to spring flow, seepage through highly permeable streambeds, or irrigation diversions.

A computer program (idregeq.exe) automates the calculations required for the regional regression calculations. Results from this program comprise calculated peak flows, site-specific standard errors of prediction, and the 90-percent confidence intervals for the estimates.

\section{REFERENCES CITED}

Berenbrock, Charles, 2002, Estimating the magnitude of peak flows at selected recurrence intervals for streams in Idaho: U.S. Geological Survey WaterResources Investigations Report 02-4170, 59 p.

Bond, J.G., 1978, Geologic map of Idaho: Moscow, Idaho Bureau of Mines and Geology, 1 sheet, scale 1:500,000.

Castro, J.M., and Jackson, P.L., 2001, Bankfull discharge recurrence intervals and regional hydraulic geometry relationships: Patterns in the Pacific Northwest, USA: Journal of the American Water Resources Association, v. 37, no. 5.

Emmett, W.W., 1975, The channels and waters of the upper Salmon River area, Idaho: U.S. Geological Survey Professional Paper 870-A, 115 p.

Haan, C.T., 1977, Statistical methods in hydrology: Ames, Iowa State University Press, 378 p.

Harenberg, W.A., 1980, Using channel geometry to estimate flood flows at ungaged sites in Idaho: U.S. Geological Survey Water-Resources Investigations 80-32, 39 p.

Hedman, E.R., and Osterkamp, W.R., 1982, Streamflow characteristics related to channel geometry of streams in Western United States: U.S. Geological Survey Water-Supply Paper 2193, 17 p.

Hodgkins, Glenn, 1999, Estimating the magnitude of peak flows for streams in Maine for selected recurrence intervals: U.S. Geological Survey 
Water-Resources Investigations Report 99-4008, $45 \mathrm{p}$.

Hortness, J.E., and Berenbrock, Charles, 2001, Estimating monthly and annual streamflow statistics at ungaged sites in Idaho: U.S. Geological Survey Water-Resources Investigations Report 01 - 4093, $36 \mathrm{p}$.

Leopold, L.B., 1994, A view of the river: Cambridge, Mass., Harvard University Press, 298 p.

Molnau, M., 1995, Mean annual precipitation, 19611990, Idaho: Moscow, University of Idaho, Agricultural Engineering Department, State Climate Program, scale 1:1,000,000. Also available at URL http://snow.ag.uidaho.edu/Climate/ reports.html

National Oceanic and Atmospheric Administration, 1971, Climates of the states, climate of Idaho, in Climatography of the United States: Silver Spring, Md., no. 60-10, 18 p.

Pope, B.F., and Tasker, G.D., 1999, Estimating the magnitude and frequency of floods in rural basins of North Carolina: U.S. Geological Survey WaterResources Investigations Report 99-4114, 44 p.

Riggs, H.C., 1968, Some statistical tools in hydrology: U.S. Geological Survey Techniques of WaterResources Investigations, Book 4, Chap. A1, 39 p.

Ross, S.H., and Savage, C.N., 1967, Idaho earth science: Moscow, Idaho Bureau of Mines and Geology, $285 \mathrm{p}$.

Sando, S.K., 1998, Techniques for estimating peakflow magnitude and frequency relations for South Dakota streams: U.S. Geological Survey WaterResources Investigations Report 98-4055, 48 p.

Sauer, V.B., Thomas, W.O., Jr., Stricker, V.A., and Wilson, K.V., 1983, Flood characteristics of urban watersheds in the United States: U.S. Geological Survey Water-Supply Paper 2207, 63 p.

Stedinger, J.R., and Tasker, G.D., 1985, Regional hydrologic analysis 1-ordinary, weighted, and generalized least squares compared: American Geophysical Union, Water Resources Research, v. 21 , no. 9 , p. $1421-1432$. 
[This page intentionally left blank] 
Appendix A. Basin and climatic characteristics for streamflow-gaging stations in Idaho and bordering States used in regional regression analysis

Appendix B. Peak flows at selected recurrence intervals for streamflow-gaging stations in Idaho and bordering States used in regional regression analysis

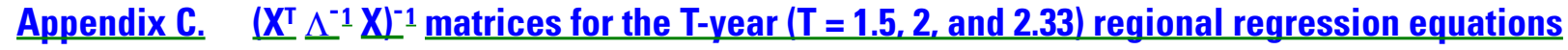
for Idaho 
[This page intentionally left blank] 
Appendix A. Basin and climatic characteristics for streamflow-gaging stations in Idaho and bordering States used in regional regression analysis

[DA, drainage area; E, mean basin elevation; F, percentage of forest cover in the basin; P, mean annual precipitation; BS, average basin slope; NF30, percentage of north-facing son NV, Nevada; OR, Oregon; WA, Washington; WY, Wyoming; Y.N.P., Yellowstone National Park]

\begin{tabular}{|c|c|c|c|c|c|c|c|c|c|}
\hline $\begin{array}{l}\text { Map } \\
\text { No. }\end{array}$ & $\begin{array}{c}\text { Gaging } \\
\text { station No. }\end{array}$ & Gaging station name & $\begin{array}{c}\text { DA } \\
\left(\mathrm{mi}^{2}\right)\end{array}$ & $\begin{array}{c}E \\
(\mathrm{ft})\end{array}$ & $\begin{array}{c}\mathbf{F} \\
\text { (percent) }\end{array}$ & $\begin{array}{c}\mathbf{P} \\
\text { (in.) }\end{array}$ & $\begin{array}{c}\text { BS } \\
\text { (percent) }\end{array}$ & $\begin{array}{c}\text { NF30 } \\
\text { (percent) }\end{array}$ & $\begin{array}{c}\mathrm{S} 30 \\
\text { (percent) }\end{array}$ \\
\hline \multicolumn{10}{|c|}{ REGION 1} \\
\hline 1 & 12305500 & Boulder Creek near Leonia, ID & 55.3 & $4,686.9$ & 92.0 & 48.30 & 37.1 & 21.8 & 69.4 \\
\hline 2 & 12309000 & Cow Creek near Bonners Ferry, ID & 17.6 & $3,189.5$ & 77.1 & 30.05 & 26.7 & 28.8 & 40.8 \\
\hline 3 & 12310800 & Trail Creek at Naples, ID & 16.0 & $3,498.6$ & 92.6 & 31.27 & 24.3 & 13.7 & 27.8 \\
\hline 4 & 12311000 & Deep Creek at Moravia, ID & 133.1 & $3,257.0$ & 72.6 & 30.36 & 21.2 & 9.7 & 27.0 \\
\hline 5 & 12313500 & Ball Creek near Bonners Ferry, ID & 26.6 & $5,194.4$ & 78.7 & 42.20 & 40.6 & 18.3 & 70.2 \\
\hline 6 & 12316800 & Mission Creek near Copeland, ID & 12.5 & $4,084.4$ & 94.5 & 29.15 & 25.4 & 5.8 & 33.2 \\
\hline 7 & 12320500 & Long Canyon Creek near Porthill, ID & 29.9 & $5,347.3$ & 89.5 & 41.32 & 46.4 & 22.7 & 81.4 \\
\hline 8 & 12321000 & Smith Creek near Porthill, ID & 71.1 & $5,054.2$ & 70.4 & 46.14 & 37.0 & 19.8 & 62.3 \\
\hline 9 & 12392100 & Trapper Creek near Clark Fork, ID & 1.1 & $4,844.3$ & 96.1 & 57.78 & 50.2 & 9.1 & 91.6 \\
\hline 10 & 12392155 & Lightning Creek at Clark Fork, ID & 115.1 & $4,648.5$ & 82.4 & 54.32 & 43.2 & 20.3 & 71.8 \\
\hline 11 & 12392300 & Pack River near Colburn, ID & 121.4 & $4,280.6$ & 62.6 & 38.15 & 32.2 & 15.9 & 52.4 \\
\hline 12 & 12392800 & Hornby Creek near Dover, ID & 3.1 & $2,519.6$ & 89.4 & 30.00 & 17.9 & 3.7 & 11.9 \\
\hline 13 & 12393500 & Priest River at outlet of Priest Lake near Coolin, ID & 596.6 & $3,941.3$ & 79.0 & 38.79 & 28.9 & 13.7 & 46.3 \\
\hline 14 & 12393600 & Binarch Creek near Coolin, ID & 10.6 & $3,258.6$ & 97.6 & 30.58 & 35.0 & 16.6 & 59.3 \\
\hline 15 & 12396000 & Calispell Creek near Dalkena, WA & 68.2 & $3,622.5$ & 79.6 & 36.71 & 30.1 & 20.0 & 51.8 \\
\hline 16 & 12408500 & Mill Creek near Colville, WA & 82.5 & $3,520.8$ & 89.4 & 37.74 & 29.6 & 13.9 & 46.2 \\
\hline 17 & 12409000 & Colville River at Kettle Falls, WA & $1,011.0$ & $2,904.3$ & 77.0 & 27.57 & 22.3 & 9.0 & 28.2 \\
\hline 18 & 12427000 & Little Spokane River at Elk, WA & 84.4 & $2,459.0$ & 65.2 & 28.22 & 13.2 & 4.1 & 10.4 \\
\hline 19 & 12429600 & Deer Creek near Chattaroy, WA & 31.0 & $2,683.7$ & 65.3 & 27.61 & 15.3 & 4.4 & 9.0 \\
\hline 20 & 12430370 & Bigelow Gulch near Spokane, WA & 4.4 & $2,245.2$ & 23.9 & 19.37 & 9.7 & 0.6 & 2.6 \\
\hline 21 & 12431000 & Little Spokane River at Dartford, WA & 634.9 & $2,397.7$ & 54.6 & 25.11 & 12.2 & 2.8 & 9.4 \\
\hline \multicolumn{10}{|c|}{ REGION 2} \\
\hline 22 & 12302500 & Granite Creek near Libby, MT & 23.7 & $5,275.3$ & 66.4 & 52.96 & 54.1 & 26.7 & 82.4 \\
\hline 23 & 12303100 & Flower Creek near Libby, MT & 11.3 & $5,466.8$ & 76.7 & 52.64 & 48.3 & 30.0 & 71.2 \\
\hline 24 & 12303500 & Lake Creek at Troy, MT & 125.0 & $4,069.2$ & 87.3 & 43.94 & 38.5 & 21.0 & 62.8 \\
\hline 25 & 12304250 & Whitetail Creek near Yaak, MT & 2.4 & $4,299.5$ & 81.5 & 31.61 & 27.4 & 0.5 & 37.2 \\
\hline 26 & 12304300 & Cyclone Creek near Yaak, MT & 5.7 & $4,627.2$ & 96.9 & 40.99 & 33.9 & 30.1 & 63.5 \\
\hline 27 & 12304400 & Fourth of July Creek near Yaak, MT & 7.8 & $4,468.8$ & 96.7 & 38.86 & 35.9 & 26.7 & 72.6 \\
\hline 28 & 12341000 & Rattlesnake Creek at Missoula, MT & 79.9 & $5,708.4$ & 79.3 & 37.04 & 36.9 & 16.7 & 57.6 \\
\hline 29 & 12345800 & Camas Creek near Hamilton, MT & 5.1 & $7,064.0$ & 51.8 & 50.32 & 42.5 & 19.5 & 73.4 \\
\hline 30 & 12347500 & Blodgett Creek near Corvallis, MT & 26.1 & $6,649.7$ & 50.4 & 60.87 & 57.0 & 32.1 & 82.8 \\
\hline 31 & 12350200 & Gash Creek near Victor, MT & 3.3 & $6,684.3$ & 73.4 & 54.70 & 37.9 & 22.0 & 69.2 \\
\hline 32 & 12350500 & Kootenai Creek near Stevensville, MT & 29.0 & $6,557.7$ & 60.4 & 55.58 & 58.8 & 28.8 & 89.6 \\
\hline 33 & 12352000 & Lolo Creek above Sleeman Creek, near Lolo, MT & 249.2 & $5,272.8$ & 84.7 & 46.82 & 35.3 & 19.1 & 58.9 \\
\hline
\end{tabular}


Appendix A. Basin and climatic characteristics for streamflow-gaging stations in Idaho and bordering States used in regional regression analysis--Continued

\begin{tabular}{|c|c|c|c|c|c|c|c|c|c|}
\hline $\begin{array}{l}\text { Map } \\
\text { No. }\end{array}$ & $\begin{array}{c}\text { Gaging } \\
\text { station No. }\end{array}$ & Gaging station name & $\begin{array}{c}\text { DA } \\
\left(\mathrm{mi}^{2}\right)\end{array}$ & $\begin{array}{c}E \\
(f t)\end{array}$ & $\begin{array}{c}\mathbf{F} \\
\text { (percent) }\end{array}$ & $\begin{array}{c}P \\
\text { (in.) }\end{array}$ & $\begin{array}{c}\text { BS } \\
\text { (percent) }\end{array}$ & $\begin{array}{c}\text { NF30 } \\
\text { (percent) }\end{array}$ & $\begin{array}{c}\mathrm{S} 30 \\
\text { (percent) }\end{array}$ \\
\hline & & \multicolumn{8}{|c|}{ REGION 2 -- Continued } \\
\hline 34 & 12353800 & Thompson Creek near Superior, MT & 12.0 & $4,648.3$ & 88.2 & 39.04 & 41.2 & 27.3 & 76.2 \\
\hline 35 & 12353850 & East Fork Timber Creek near Haugan, MT & 2.6 & $4,669.2$ & 96.0 & 48.34 & 32.8 & 1.6 & 54.3 \\
\hline 36 & 12354000 & St. Regis River near St. Regis, MT & 43.6 & $4,843.4$ & 88.3 & 44.49 & 47.2 & 30.4 & 84.6 \\
\hline 37 & 12354100 & North Fork Little Joe Creek near St. Regis, MT & 14.4 & $4,854.3$ & 89.8 & 42.42 & 45.6 & 28.5 & 83.1 \\
\hline 38 & 12389500 & Thompson River near Thompson Falls, MT & 641.5 & $4,567.1$ & 85.8 & 29.56 & 30.0 & 15.9 & 47.0 \\
\hline 39 & 12390700 & Prospect Creek at Thompson Falls, MT & 181.5 & $4,437.3$ & 93.1 & 43.68 & 43.5 & 27.8 & 79.6 \\
\hline 40 & 12411000 & $\begin{array}{l}\text { North Fork Coeur d'Alene River above Shoshone Creek, } \\
\text { near Prichard, ID }\end{array}$ & 334.0 & $3,947.0$ & 89.7 & 48.25 & 40.8 & 24.7 & 75.6 \\
\hline 41 & 12413000 & North Fork Coeur d'Alene River at Enaville, ID & 893.7 & $3,835.9$ & 88.9 & 45.38 & 41.9 & 25.4 & 77.6 \\
\hline 42 & 12413100 & Boulder Creek at Mullan, ID & 3.1 & $5,212.4$ & 93.2 & 49.41 & 46.7 & 33.1 & 83.0 \\
\hline 43 & 12413140 & Placer Creek at Wallace, ID & 15.0 & $4,411.0$ & 94.2 & 41.53 & 49.6 & 31.2 & 88.8 \\
\hline 44 & 12413150 & South Fork Coeur d'Alene River at Silverton, ID & 105.6 & $4,615.4$ & 89.8 & 42.52 & 45.8 & 27.5 & 82.3 \\
\hline 45 & 12413200 & Montgomery Creek near Kellogg, ID & 4.5 & $3,648.3$ & 91.8 & 40.23 & 48.0 & 13.6 & 89.3 \\
\hline 46 & 12413210 & South Fork Coeur d'Alene at Elizabeth Park near Kellogg, ID & 181.8 & $4,301.2$ & 88.5 & 43.34 & 45.8 & 27.2 & 82.5 \\
\hline 47 & 12413470 & South Fork Coeur d'Alene River near Pinehurst, ID & 287.1 & $4,096.4$ & 83.5 & 45.09 & 44.6 & 26.9 & 80.7 \\
\hline 48 & 12413500 & Coeur d'Alene River at Cataldo, ID & $1,207.4$ & $3,878.0$ & 87.3 & 45.01 & 42.3 & 25.5 & 77.8 \\
\hline 49 & 12413700 & Latour Creek near Cataldo, ID & 24.8 & $4,316.0$ & 85.6 & 54.84 & 41.8 & 27.9 & 81.6 \\
\hline 50 & 12414500 & St. Joe River at Calder, ID & $1,024.5$ & $4,545.6$ & 89.8 & 46.95 & 41.3 & 24.7 & 74.4 \\
\hline 51 & 12414900 & St. Maries River near Santa, ID & 272.6 & $3,592.6$ & 80.6 & 37.73 & 25.1 & 12.5 & 34.9 \\
\hline 52 & 12415000 & St. Maries River at Lotus, ID & 434.5 & $3,465.5$ & 82.2 & 35.63 & 23.8 & 11.4 & 31.7 \\
\hline 53 & 12415100 & Cherry Creek near St. Maries, ID & 7.1 & $3,308.1$ & 86.4 & 31.71 & 30.3 & 23.5 & 51.3 \\
\hline 54 & 12415200 & Plummer Creek Tributary at Plummer, ID & 2.0 & $2,966.3$ & 35.9 & 20.00 & 15.2 & 1.5 & 9.9 \\
\hline 55 & 12416000 & Hayden Creek below North Fork, near Hayden Lake, ID & 21.5 & $3,564.7$ & 95.1 & 38.75 & 41.8 & 25.3 & 81.2 \\
\hline 56 & 13336500 & Selway River near Lowell, ID & $1,913.1$ & $5,511.8$ & 82.8 & 40.58 & 44.2 & 24.1 & 785.6 \\
\hline 57 & 13336600 & Swiftwater Creek near Lowell, ID & 6.2 & $3,814.8$ & 93.7 & 33.22 & 42.7 & 39.6 & 80.2 \\
\hline 58 & 13336650 & East Fork Papoose Creek near Powell Ranger Station, ID & 4.5 & $4,832.2$ & 82.4 & 47.61 & 47.2 & 17.1 & 87.9 \\
\hline 59 & 13336850 & Weir Creek near Powell Ranger Station, ID & 12.2 & $4,817.1$ & 86.5 & 48.18 & 48.7 & 13.9 & 88.5 \\
\hline 60 & 13336900 & Fish Creek near Lowell, ID & 88.3 & $4,467.2$ & 91.3 & 46.34 & 34.7 & 13.7 & 55.7 \\
\hline 61 & 13337000 & Lochsa River near Lowell, ID & $1,179.4$ & $5,197.2$ & 88.2 & 46.62 & 38.5 & 20.4 & 63.5 \\
\hline 62 & 13340500 & North Fork Clearwater River at Bungalow Ranger Station, ID & 997.5 & $4,888.8$ & 82.2 & 52.47 & 39.0 & 22.1 & 68.1 \\
\hline 63 & 13340600 & North Fork Clearwater River near Canyon Ranger Station, ID & $1,294.2$ & $4,732.9$ & 82.9 & 51.40 & 40.4 & 22.7 & 69.9 \\
\hline 64 & 13341300 & Bloom Creek near Bovill, ID & 3.0 & $3,716.0$ & 86.8 & 48.07 & 32.0 & 27.6 & 55.6 \\
\hline \multirow[t]{2}{*}{65} & 13341400 & East Fork Potlatch River near Bovill, ID & 42.7 & $3,617.2$ & 86.0 & 42.67 & 26.3 & 14.0 & 36.4 \\
\hline & & \multicolumn{8}{|c|}{ REGION 3} \\
\hline 66 & 12423550 & Hangman Creek Tributary near Latah, WA & 2.3 & $2,693.4$ & 1.1 & 20.41 & 11.4 & 1.7 & 1.9 \\
\hline 67 & 12423700 & South Fork Rock Creek Tributary near Fairfield, WA & 0.6 & $2,720.9$ & 7.9 & 19.91 & 11.0 & 2.6 & 3.2 \\
\hline 68 & 12423900 & Stevens Creek Tributary near Moran, WA & 2.0 & $2,671.8$ & 9.9 & 18.97 & 17.2 & 0.9 & 2.0 \\
\hline 69 & 12424000 & Hangman Creek at Spokane, WA & 674.9 & $2,647.1$ & 19.4 & 20.83 & 10.5 & 2.3 & 6.7 \\
\hline
\end{tabular}


Appendix A. Basin and climatic characteristics for streamflow-gaging stations in Idaho and bordering States used in regional regression analysis--Continued

\begin{tabular}{|c|c|c|c|c|c|c|c|c|c|}
\hline $\begin{array}{l}\text { Map } \\
\text { No. }\end{array}$ & $\begin{array}{c}\text { Gaging } \\
\text { station No. }\end{array}$ & Gaging station name & $\begin{array}{c}\text { DA } \\
\left(\mathrm{mi}^{2}\right)\end{array}$ & $\begin{array}{c}E \\
(f t)\end{array}$ & $\begin{array}{c}\mathbf{F} \\
\text { (percent) }\end{array}$ & $\begin{array}{l}P \\
\text { (in.) }\end{array}$ & $\begin{array}{c}\text { BS } \\
\text { (percent) }\end{array}$ & $\begin{array}{c}\text { NF30 } \\
\text { (percent) }\end{array}$ & $\begin{array}{c}\mathrm{S} 30 \\
\text { (percent) }\end{array}$ \\
\hline & & \multicolumn{8}{|c|}{ REGION 3 -- Continued } \\
\hline 70 & 13334700 & Asotin Creek below Kearney Gulch near Asotin, WA & 170.5 & $3,752.2$ & 30.5 & 23.01 & 35.4 & 20.7 & 57.5 \\
\hline 71 & 13335200 & Critchfield Draw near Clarkston, WA & 2.0 & $1,472.6$ & 0.2 & 11.90 & 12.7 & 0.9 & 3.9 \\
\hline 72 & 13341100 & Cold Springs Creek near Craigmont, ID & 8.2 & $4,040.1$ & 10.7 & 20.00 & 8.9 & 0.2 & 1.0 \\
\hline 73 & 13341500 & Potlatch River at Kendrick, ID & 453.7 & $2,969.1$ & 59.8 & 29.51 & 18.2 & 5.5 & 17.8 \\
\hline 74 & 13342450 & Lapwai Creek near Lapwai, ID & 268.9 & $3,149.2$ & 30.7 & 19.31 & 18.9 & 7.7 & 22.2 \\
\hline 75 & 13343450 & Dry Creek at mouth near Clarkston, WA & 7.5 & $1,458.4$ & 0.2 & 12.08 & 8.6 & 0.1 & 1.4 \\
\hline 76 & 13343800 & Meadow Creek near Central Ferry, WA & 67.2 & $1,898.5$ & 0.0 & 16.12 & 14.2 & 2.3 & 6.7 \\
\hline 77 & 13344500 & Tucannon River near Starbuck, WA & 431.8 & $2,943.7$ & 23.7 & 23.98 & 26.4 & 11.9 & 36.0 \\
\hline 78 & 13344700 & Deep Creek Tributary near Polatch, ID & 2.9 & $3,156.8$ & 87.6 & 28.67 & 24.3 & 17.8 & 27.1 \\
\hline 79 & 13344800 & Deep Creek near Potlatch, ID & 35.8 & $2,977.9$ & 46.4 & 24.92 & 18.7 & 5.0 & 19.8 \\
\hline 80 & 13345000 & Palouse River near Potlatch, ID & 316.0 & $3,165.1$ & 63.4 & 30.07 & 21.2 & 9.0 & 25.8 \\
\hline 81 & 13346100 & Palouse River at Colfax, WA & 491.7 & $2,963.6$ & 41.7 & 26.93 & 17.7 & 6.2 & 17.8 \\
\hline 82 & 13346300 & Crumarine Creek near Moscow, ID & 2.4 & $3,694.1$ & 79.3 & 29.55 & 27.4 & 10.0 & 41.1 \\
\hline 83 & 13346800 & Paradise Creek at University of Idaho, at Moscow, ID & 17.6 & $2,844.2$ & 12.5 & 24.53 & 11.8 & 1.0 & 6.0 \\
\hline 84 & 13348000 & South Fork Palouse River at Pullman, WA & 126.9 & $2,745.5$ & 6.9 & 23.76 & 11.9 & 0.8 & 3.3 \\
\hline 85 & 13348500 & Missouri Flat Creek at Pullman, WA & 27.1 & $2,652.2$ & 0.6 & 23.23 & 10.0 & 0.0 & 0.0 \\
\hline 86 & 13349210 & Palouse River below South Fork at Colfax, WA & 788.7 & $2,842.0$ & 27.4 & 25.33 & 15.5 & 4.2 & 12.1 \\
\hline 87 & 13349400 & Pine Creek at Pine City, WA & 304.6 & $2,527.0$ & 1.6 & 19.00 & 9.1 & 0.5 & 1.2 \\
\hline 88 & 13350500 & Union Flat Creek near Colfax, WA & 189.8 & $2,691.9$ & 0.0 & 20.97 & 10.5 & 0.5 & 1.1 \\
\hline 89 & 14016000 & Dry Creek near Walla Walla, WA & 48.5 & $2,342.9$ & 18.4 & 30.10 & 21.4 & 8.9 & 23.7 \\
\hline 90 & 14016500 & East Fork Touchet River near Dayton, WA & 106.2 & $3,820.0$ & 59.8 & 42.10 & 38.9 & 21.0 & 65.9 \\
\hline \multirow[t]{2}{*}{91} & 14017000 & Touchet River at Bolles, WA & 363.3 & $2,928.8$ & 31.7 & 30.50 & 27.3 & 13.4 & 38.5 \\
\hline & & \multicolumn{8}{|c|}{ REGION 4} \\
\hline 92 & 13185500 & Cottonwood Creek at Arrowrock Reservoir, ID & 20.8 & $5,198.1$ & 36.8 & 19.08 & 39.8 & 18.4 & 70.7 \\
\hline 93 & 13196500 & Bannock Creek near Idaho City, ID & 4.8 & $5,313.2$ & 60.4 & 22.08 & 32.9 & 26.2 & 57.4 \\
\hline 94 & 13200000 & Mores Creek above Robie Creek, near Arrowrock Dam, ID & 397.0 & $5,070.8$ & 66.3 & 24.76 & 31.3 & 16.7 & 51.0 \\
\hline 95 & 13200500 & Robie Creek near Arrowrock Dam, ID & 16.0 & $4,680.6$ & 65.0 & 23.34 & 39.8 & 23.4 & 70.6 \\
\hline 96 & 13201000 & Mores Creek near Arrowrock, ID & 424.4 & $5,024.2$ & 65.0 & 24.48 & 31.7 & 17.0 & 52.0 \\
\hline 97 & 13207000 & Spring Valley Creek near Eagle, ID & 19.2 & $4,017.4$ & 8.0 & 19.42 & 24.3 & 9.3 & 30.2 \\
\hline 98 & 13207500 & Dry Creek near Eagle, ID & 59.4 & $3,963.4$ & 11.7 & 20.39 & 25.3 & 8.8 & 34.3 \\
\hline 99 & 13216500 & $\begin{array}{l}\text { North Fork Malheur River above Beulah Reservoir near } \\
\text { Beulah, OR }\end{array}$ & 342.5 & $5,360.8$ & 52.7 & 23.79 & 21.6 & 6.0 & 23.2 \\
\hline 100 & 13248900 & Cottonwood Creek near Horseshoe Bend, ID & 7.0 & $3,882.5$ & 0.0 & 17.16 & 23.9 & 15.2 & 26.3 \\
\hline 101 & 13250600 & Big Willow Creek near Emmett, ID & 55.2 & $4,099.3$ & 4.8 & 15.88 & 23.6 & 7.3 & 28.0 \\
\hline 102 & 13250650 & Fourmile Creek near Emmett, ID & 6.2 & $3,804.1$ & 1.7 & 12.88 & 22.9 & 2.9 & 21.4 \\
\hline 103 & 13251300 & West Branch Weiser River near Tamarack, ID & 4.0 & $4,947.6$ & 81.5 & 39.75 & 27.3 & 3.2 & 41.5 \\
\hline 104 & 13251500 & Weiser River at Tamarack, ID & 36.6 & $4,654.2$ & 87.8 & 34.61 & 22.3 & 4.9 & 27.1 \\
\hline 105 & 13252500 & East Fork Weiser River near Council, ID & 2.3 & $6,883.5$ & 76.0 & 40.00 & 27.0 & 16.9 & 36.5 \\
\hline
\end{tabular}


Appendix A. Basin and climatic characteristics for streamflow-gaging stations in Idaho and bordering States used in regional regression analysis--Continued

\begin{tabular}{|c|c|c|c|c|c|c|c|c|c|}
\hline $\begin{array}{l}\text { Map } \\
\text { No. }\end{array}$ & $\begin{array}{c}\text { Gaging } \\
\text { station No. }\end{array}$ & Gaging station name & $\begin{array}{c}\text { DA } \\
\left(\mathrm{mi}^{2}\right)\end{array}$ & $\begin{array}{c}E \\
(\mathrm{ft})\end{array}$ & $\begin{array}{c}\mathbf{F} \\
\text { (percent) }\end{array}$ & $\begin{array}{c}\mathbf{P} \\
\text { (in.) } \\
\end{array}$ & $\begin{array}{c}\text { BS } \\
\text { (percent) }\end{array}$ & $\begin{array}{c}\text { NF30 } \\
\text { (percent) }\end{array}$ & $\begin{array}{c}\mathrm{S} 30 \\
\text { (percent) }\end{array}$ \\
\hline & & \multicolumn{8}{|c|}{ REGION 4 -- Continued } \\
\hline 106 & 13253500 & Weiser River at Starkey, ID & 105.4 & $4,969.7$ & 88.1 & 32.34 & 26.5 & 10.7 & 38.0 \\
\hline 107 & 13256000 & Weiser River near Council, ID & 391.9 & $4,668.2$ & 64.6 & 29.64 & 24.2 & 9.6 & 32.7 \\
\hline 108 & 13257000 & Middle Fork Weiser River near Mesa, ID & 86.1 & $5,430.2$ & 74.1 & 34.00 & 27.4 & 11.1 & 38.3 \\
\hline 109 & 13258500 & Weiser River near Cambridge, ID & 596.4 & $4,636.5$ & 58.2 & 29.23 & 23.5 & 8.7 & 30.6 \\
\hline 110 & 13260000 & Pine Creek near Cambridge, ID & 55.3 & $4,751.8$ & 42.3 & 22.43 & 26.4 & 10.0 & 37.9 \\
\hline 111 & 13261000 & Little Weiser River near Indian Valley, ID & 79.5 & $5,313.9$ & 67.1 & 28.23 & 26.9 & 11.2 & 36.5 \\
\hline 112 & 13266000 & Weiser River near Weiser, ID & $1,448.3$ & $4,141.3$ & 32.7 & 22.23 & 19.3 & 6.4 & 22.1 \\
\hline 113 & 13267000 & Mann Creek near Weiser, ID & 56.8 & $4,846.2$ & 55.4 & 22.12 & 31.6 & 10.6 & 53.4 \\
\hline 114 & 13267100 & Deer Creek near Midvale, ID & 4.3 & $3,233.7$ & 1.1 & 10.00 & 15.7 & 0.5 & 6.1 \\
\hline 115 & 13269300 & North Fork Burnt River near Whitney, OR & 110.8 & $4,901.1$ & 81.6 & 25.11 & 18.7 & 4.5 & 17.7 \\
\hline 116 & 13270800 & South Fork Burnt River above Barney Creek near Unity, OR & 38.9 & $5,823.5$ & 91.6 & 28.59 & 28.2 & 16.9 & 42.0 \\
\hline 117 & 13275500 & Powder River near Baker, OR & 205.2 & $5,224.6$ & 74.5 & 24.67 & 26.5 & 9.6 & 40.8 \\
\hline 118 & 13288200 & Eagle Creek above Skull Creek near New Bridge, OR & 155.7 & $5,742.6$ & 67.6 & 47.53 & 40.5 & 14.5 & 63.7 \\
\hline 119 & 13289100 & Immigrant Gulch near Richlavel, OR & 6.7 & $3,581.4$ & 1.4 & 24.97 & 25.4 & 3.1 & 32.3 \\
\hline 120 & 13289600 & East Brownlee Creek at Brownlee Ranger Station, ID & 7.4 & $5,913.0$ & 79.2 & 30.00 & 44.9 & 18.5 & 78.9 \\
\hline 121 & 13289960 & Wildhorse River at Brownlee Dam, ID & 177.1 & $5,037.5$ & 62.2 & 27.53 & 29.4 & 14.3 & 43.3 \\
\hline 122 & 13290190 & Pine Creek near Oxbow, OR & 298.5 & $4,287.7$ & 50.2 & 33.71 & 27.4 & 9.8 & 40.0 \\
\hline 123 & 13291000 & Imnaha River above Gumboot Creek, OR & 99.8 & $6,374.4$ & 64.6 & 56.25 & 37.0 & 21.0 & 58.7 \\
\hline 124 & 13291200 & Mahogany Creek near Homestead, OR & 4.1 & $5,192.1$ & 75.4 & 37.19 & 33.5 & 18.5 & 53.2 \\
\hline 125 & 13315500 & Mud Creek near Tamarack, ID & 15.1 & $4,742.2$ & 93.0 & 35.36 & 27.4 & 6.7 & 45.0 \\
\hline 126 & 13316500 & Little Salmon River at Riggins, ID & 576.1 & $5,421.1$ & 71.8 & 29.61 & 33.4 & 15.5 & 51.5 \\
\hline 127 & 13316800 & North Fork Skookumchuck Creek near White Bird, ID & 15.3 & $5,031.2$ & 69.3 & 30.22 & 30.6 & 15.8 & 44.2 \\
\hline 128 & 13317000 & Salmon River at White Bird, ID & $13,418.3$ & $6,753.8$ & 58.3 & 24.72 & 37.7 & 19.1 & 60.3 \\
\hline 129 & 13317200 & Johns Creek near Grangeville, ID & 5.0 & $3,961.5$ & 33.1 & 24.22 & 11.7 & 8.5 & 10.9 \\
\hline 130 & 13319000 & Grande Ronde River at La Grande, OR & 687.4 & $4,582.0$ & 68.4 & 27.57 & 20.3 & 6.5 & 21.8 \\
\hline 131 & 13320000 & Catherine Creek near Union, OR & 104.1 & $5,263.8$ & 85.9 & 39.66 & 28.6 & 10.6 & 40.8 \\
\hline 132 & 13323600 & Indian Creek near Imbler, OR & 24.8 & $5,515.7$ & 77.1 & 43.58 & 21.3 & 6.3 & 20.8 \\
\hline 133 & 13329500 & Hurricane Creek near Joseph, OR & 29.6 & $7,461.3$ & 47.0 & 64.64 & 57.2 & 22.9 & 87.0 \\
\hline 134 & 13330000 & Lostine River near Lostine, OR & 71.5 & $6,893.5$ & 52.1 & 56.69 & 49.2 & 22.1 & 77.2 \\
\hline 135 & 13330500 & Bear Creek near Wallowa, OR & 72.1 & $5,804.7$ & 67.2 & 44.74 & 45.6 & 23.2 & 75.0 \\
\hline 136 & 13331500 & Minam River at Minam, OR & 239.2 & $5,699.5$ & 66.4 & 46.47 & 43.5 & 21.3 & 70.5 \\
\hline 137 & 13337200 & Red Horse Creek near Elk City, ID & 9.1 & $5,052.5$ & 93.9 & 36.37 & 27.9 & 11.9 & 42.3 \\
\hline 138 & 13337500 & South Fork Clearwater River near Elk City, ID & 260.8 & $5,095.1$ & 91.7 & 35.30 & 24.1 & 10.1 & 28.8 \\
\hline 139 & 13337700 & Peasley Creek near Golden, ID & 14.2 & $4,880.8$ & 94.3 & 35.81 & 35.0 & 9.5 & 57.9 \\
\hline 140 & 13338000 & South Fork Clearwater River near Grangeville, ID & 843.4 & $5,116.5$ & 91.8 & 34.88 & 29.7 & 14.0 & 42.4 \\
\hline 141 & 13338200 & Sally Ann Creek near Stites, ID & 13.8 & $3,142.8$ & 57.6 & 31.08 & 24.8 & 16.6 & 32.0 \\
\hline 142 & 13338500 & South Fork Clearwater River at Stites, ID & $1,168.3$ & $4,546.6$ & 70.5 & 31.31 & 25.7 & 11.9 & 35.1 \\
\hline 143 & 13339000 & Clearwater River at Kamiah, ID & $4,827.4$ & $4,956.2$ & 77.4 & 38.29 & 36.2 & 19.1 & 58.6 \\
\hline
\end{tabular}


Appendix A. Basin and climatic characteristics for streamflow-gaging stations in Idaho and bordering States used in regional regression analysis--Continued

\begin{tabular}{|c|c|c|c|c|c|c|c|c|c|}
\hline $\begin{array}{l}\text { Map } \\
\text { No. }\end{array}$ & $\begin{array}{c}\text { Gaging } \\
\text { station No. }\end{array}$ & Gaging station name & $\begin{array}{c}\text { DA } \\
\left(\mathrm{mi}^{2}\right)\end{array}$ & $\begin{array}{c}E \\
(f t)\end{array}$ & $\begin{array}{c}\text { F } \\
\text { (percent) }\end{array}$ & $\begin{array}{c}P \\
\text { (in.) }\end{array}$ & $\begin{array}{c}\text { BS } \\
\text { (percent) }\end{array}$ & $\begin{array}{c}\text { NF30 } \\
\text { (percent) }\end{array}$ & $\begin{array}{c}\mathrm{S} 30 \\
\text { (percent) }\end{array}$ \\
\hline & & \multicolumn{8}{|c|}{ REGION 4 -- Continued } \\
\hline 144 & 13339500 & Lolo Creek near Greer, ID & 241.4 & $3,528.6$ & 84.1 & 31.53 & 22.6 & 8.4 & 25.5 \\
\hline 145 & 13339700 & Canal Gulch Creek at Pierce Ranger Station, ID & 6.4 & $3,539.5$ & 92.2 & 40.00 & 17.5 & 1.1 & 8.5 \\
\hline 146 & 13339900 & Deer Creek near Orofino, ID & 5.2 & $2,955.8$ & 82.6 & 29.82 & 18.0 & 7.2 & 17.7 \\
\hline 147 & 13340000 & Clearwater River at Orofino, ID & $5,507.9$ & $4,736.4$ & 76.6 & 37.36 & 34.4 & 17.7 & 54.5 \\
\hline 148 & 14010000 & South Fork Walla Walla River near Milton, OR & 61.9 & $4,273.1$ & 68.3 & 46.44 & 46.3 & 21.9 & 74.7 \\
\hline 149 & 14011000 & North Fork Walla Walla River near Milton, OR & 42.6 & $3,640.0$ & 57.2 & 42.17 & 42.1 & 23.9 & 71.2 \\
\hline 150 & 14013000 & Mill Creek near Walla Walla, WA & 58.8 & $3,933.2$ & 68.6 & 47.97 & 50.5 & 28.8 & 85.5 \\
\hline \multirow[t]{2}{*}{151} & 14013500 & Blue Creek near Walla Walla, WA & 17.1 & $3,136.4$ & 45.7 & 40.52 & 38.3 & 24.9 & 68.8 \\
\hline & & \multicolumn{8}{|c|}{ REGION 5} \\
\hline 152 & 12343400 & East Fork Bitterroot River near Conner, MT & 379.3 & $6,361.7$ & 78.6 & 28.42 & 33.2 & 18.1 & 55.1 \\
\hline 153 & 12346500 & Skalkaho Creek near Hamilton, MT & 88.1 & $6,676.0$ & 86.4 & 29.55 & 38.8 & 22.5 & 67.5 \\
\hline 154 & 12351000 & Burnt Fork Bitterroot River near Stevensville, MT & 73.0 & $6,495.2$ & 79.6 & 30.60 & 36.5 & 21.3 & 62.0 \\
\hline 155 & 12351400 & Eightmile Creek near Florence, MT & 20.8 & $5,389.4$ & 62.1 & 24.51 & 39.1 & 24.2 & 69.3 \\
\hline 156 & 13135200 & Prairie Creek near Ketchum, ID & 17.3 & $8,558.1$ & 59.0 & 34.44 & 45.9 & 24.1 & 72.1 \\
\hline 157 & 13135500 & Big Wood River near Ketchum, ID & 137.5 & $8,204.0$ & 55.8 & 31.42 & 40.6 & 20.8 & 67.5 \\
\hline 158 & 13135800 & Adams Gulch near Ketchum, ID & 10.5 & $7,373.5$ & 61.5 & 30.69 & 42.5 & 32.9 & 79.2 \\
\hline 159 & 13136500 & Warm Springs Creek at Guyer Hot Springs, near Ketchum, ID & 92.6 & $7,696.0$ & 59.7 & 35.77 & 42.6 & 23.1 & 77.8 \\
\hline 160 & 13139500 & Big Wood River at Hailey, ID & 627.6 & $7,685.6$ & 43.2 & 29.35 & 42.7 & 22.1 & 74.0 \\
\hline 161 & 13141000 & Big Wood River near Bellevue, ID & 786.2 & $7,347.3$ & 35.5 & 26.45 & 40.2 & 20.8 & 69.3 \\
\hline 162 & 13141400 & Deer Creek near Fairfield, ID & 11.8 & $6,496.3$ & 30.1 & 19.80 & 33.4 & 13.1 & 62.2 \\
\hline 163 & 13184200 & Roaring River near Rocky Bar, ID & 22.1 & $7,274.7$ & 61.3 & 41.26 & 32.6 & 15.7 & 46.8 \\
\hline 164 & 13184800 & Beaver Creek near Lowman, ID & 10.0 & $5,796.4$ & 52.1 & 32.14 & 24.2 & 7.8 & 29.9 \\
\hline 165 & 13185000 & Boise River near Twin Springs, ID & 831.6 & $6,415.7$ & 50.2 & 32.42 & 44.3 & 23.2 & 75.1 \\
\hline 166 & 13186000 & South Fork Boise River near Featherville, ID & 641.6 & $7,025.2$ & 50.6 & 34.72 & 42.1 & 21.5 & 74.4 \\
\hline 167 & 13186500 & Lime Creek near Bennett, ID & 133.6 & $6,276.7$ & 22.4 & 22.40 & 29.3 & 11.4 & 47.3 \\
\hline 168 & 13187000 & Fall Creek near Anderson Ranch Dam, ID & 55.6 & $6,171.1$ & 59.2 & 32.16 & 33.6 & 14.0 & 59.3 \\
\hline 169 & 13234300 & Fivemile Creek nr Lowman, ID & 11.3 & $6,623.7$ & 49.9 & 32.33 & 44.6 & 14.7 & 76.2 \\
\hline 170 & 13235000 & South Fork Payette River at Lowman, ID & 449.3 & $6,824.5$ & 54.3 & 34.51 & 46.7 & 23.2 & 76.6 \\
\hline 171 & 13235100 & Rock Creek at Lowman, ID & 16.5 & $5,793.4$ & 63.3 & 31.40 & 39.5 & 25.9 & 72.2 \\
\hline 172 & 13237300 & Danskin Creek near Crimes Pass, ID & 10.0 & $4,779.2$ & 68.8 & 26.49 & 46.3 & 16.1 & 83.7 \\
\hline 173 & 13238300 & Deep Creek near McCall, ID & 3.6 & $7,255.3$ & 60.3 & 49.73 & 22.5 & 2.5 & 23.4 \\
\hline 174 & 13240000 & Lake Fork Payette River above Jumbo Creek, near McCall, ID & 48.7 & $6,921.9$ & 71.6 & 37.22 & 42.1 & 16.5 & 67.9 \\
\hline 175 & 13240500 & Lake Fork Payette River above Reservoir near McCall, ID & 51.7 & $6,905.7$ & 72.6 & 36.82 & 41.0 & 15.7 & 65.6 \\
\hline 176 & 13245400 & Tripod Creek at Smiths Ferry, ID & 8.6 & $5,514.1$ & 87.7 & 28.13 & 19.8 & 3.6 & 18.3 \\
\hline 177 & 13292400 & Beaver Creek near Stanley, ID & 14.9 & $8,255.9$ & 57.7 & 41.59 & 35.4 & 22.1 & 56.9 \\
\hline 178 & 13292500 & Salmon River near Obsidian, ID & 93.9 & $8,181.1$ & 56.9 & 34.66 & 32.8 & 17.8 & 53.1 \\
\hline 179 & 13293000 & Alturas Lake Creek near Obsidian, ID & 35.6 & $8,161.5$ & 47.1 & 44.47 & 37.6 & 19.0 & 60.4 \\
\hline 180 & 13295000 & Valley Creek at Stanley, ID & 148.9 & $7,318.8$ & 63.0 & 23.94 & 26.1 & 12.0 & 37.0 \\
\hline
\end{tabular}


Appendix A. Basin and climatic characteristics for streamflow-gaging stations in Idaho and bordering States used in regional regression analysis--Continued

\begin{tabular}{|c|c|c|c|c|c|c|c|c|c|}
\hline $\begin{array}{l}\text { Map } \\
\text { No. }\end{array}$ & $\begin{array}{c}\text { Gaging } \\
\text { station No. }\end{array}$ & Gaging station name & $\begin{array}{c}\text { DA } \\
\left(\mathrm{mi}^{2}\right)\end{array}$ & $\begin{array}{c}E \\
(f t)\end{array}$ & $\begin{array}{c}\mathbf{F} \\
\text { (percent) }\end{array}$ & $\begin{array}{c}\mathbf{P} \\
\text { (in.) } \\
\end{array}$ & $\begin{array}{c}\text { BS } \\
\text { (percent) }\end{array}$ & $\begin{array}{c}\text { NF30 } \\
\text { (percent) }\end{array}$ & $\begin{array}{c}\mathrm{S} 30 \\
\text { (percent) }\end{array}$ \\
\hline & & \multicolumn{8}{|c|}{ REGION 5 -- Continued } \\
\hline 181 & 13295500 & Salmon River below Valley Creek, at Stanley, ID & 510.4 & $7,786.2$ & 54.9 & 29.61 & 30.4 & 14.6 & 45.2 \\
\hline 182 & 13296000 & Yankee Fork Salmon River near Clayton, ID & 187.3 & $7,992.1$ & 74.5 & 27.11 & 41.0 & 22.7 & 71.1 \\
\hline 183 & 13296500 & Salmon River below Yankee Fork, near Clayton, ID & 811.1 & $7,791.6$ & 61.9 & 27.95 & 33.6 & 17.1 & 53.7 \\
\hline 184 & 13297100 & Peach Creek near Clayton, ID & 7.6 & $7,809.8$ & 78.1 & 22.53 & 47.1 & 16.6 & 87.1 \\
\hline 185 & 13308500 & Middle Fork Salmon River near Cape Horn, ID & 133.8 & $7,482.6$ & 70.8 & 28.40 & 26.6 & 11.6 & 40.2 \\
\hline 186 & 13309000 & Bear Valley Creek near Cape Horn, ID & 181.7 & $7,060.3$ & 70.1 & 30.02 & 20.2 & 7.6 & 24.7 \\
\hline 187 & 13309220 & Middle Fork Salmon River near Yellow Pine, ID & $1,038.7$ & $7,189.7$ & 68.9 & 29.00 & 38.4 & 20.3 & 64.1 \\
\hline 188 & 13310000 & Big Creek near Big Creek, ID & 451.5 & $6,981.2$ & 78.6 & 28.71 & 44.3 & 24.6 & 74.0 \\
\hline 189 & 13310500 & South Fork Salmon River near Knox, ID & 91.7 & $6,631.3$ & 88.7 & 37.46 & 31.7 & 18.3 & 52.9 \\
\hline 190 & 13310700 & South Fork Salmon River near Krassel Ranger Station, ID & 329.3 & $6,381.8$ & 83.7 & 33.62 & 38.0 & 19.9 & 63.8 \\
\hline 191 & 13311000 & East Fork South Fork Salmon River at Stibnite, ID & 19.3 & $7,724.4$ & 83.7 & 34.05 & 35.3 & 20.4 & 62.6 \\
\hline 192 & 13311500 & East Fork South Fork Salmon River near Stibnite, ID & 42.9 & $7,619.9$ & 77.3 & 30.88 & 40.8 & 22.8 & 72.5 \\
\hline 193 & 13312000 & East Fork South Fork Salmon River near Yellow Pine, ID & 106.9 & $7,404.6$ & 78.2 & 30.02 & 41.7 & 22.2 & 73.0 \\
\hline 194 & 13313000 & Johnson Creek at Yellow Pine, ID & 216.4 & $7,135.2$ & 91.7 & 34.31 & 28.2 & 11.3 & 40.7 \\
\hline 195 & 13313500 & Secesh River near Burgdorf, ID & 100.5 & $6,963.9$ & 82.7 & 43.91 & 24.8 & 10.7 & 61.8 \\
\hline 196 & 13314000 & South Fork Salmon River near Warren, ID & $1,164.0$ & $6,696.9$ & 81.2 & 33.15 & 37.4 & 18.4 & 60.5 \\
\hline \multirow[t]{2}{*}{197} & 13315000 & Salmon River near French Creek, ID & $12,228.0$ & $6,913.7$ & 57.4 & 24.41 & 37.8 & 19.3 & 60.4 \\
\hline & & \multicolumn{8}{|c|}{ REGION 6} \\
\hline 198 & 06013500 & Big Sheep Creek below Muddy Creek near Dell, MT & 277.0 & $7,928.2$ & 14.5 & 18.82 & 24.1 & 10.1 & 31.8 \\
\hline 199 & 06015500 & Grasshopper Creek near Dillon, MT & 349.0 & $6,940.1$ & 28.9 & 19.22 & 18.8 & 5.6 & 19.6 \\
\hline 200 & 06019500 & Ruby River above reservoir near Alder, MT & 525.5 & $7,235.2$ & 26.0 & 22.93 & 20.1 & 6.2 & 20.5 \\
\hline 201 & 13108500 & Camas Creek at Eighteenmile Shearing Corral, near Kilgore, II & 228.4 & $6,943.3$ & 39.4 & 26.84 & 12.8 & 3.2 & 12.8 \\
\hline 202 & 13112000 & Camas Creek at Camas, ID & 393.9 & $6,428.8$ & 22.9 & 21.10 & 8.6 & 1.9 & 7.5 \\
\hline 203 & 13112900 & Huntley Canyon at Spencer, ID & 4.0 & $6,820.0$ & 58.0 & 17.33 & 24.8 & 11.2 & 33.1 \\
\hline 204 & 13113000 & Beaver Creek at Spencer, ID & 123.2 & $7,027.5$ & 29.9 & 20.29 & 19.6 & 7.9 & 23.5 \\
\hline 205 & 13113500 & Beaver Creek at Dubois, ID & 238.7 & $6,696.9$ & 24.4 & 19.42 & 16.7 & 5.1 & 18.8 \\
\hline 206 & 13117200 & Main Fork near Goldburg, ID & 16.2 & $8,734.8$ & 49.7 & 26.30 & 32.6 & 10.9 & 53.0 \\
\hline 207 & 13117300 & Sawmill Creek near Goldburg, ID & 74.2 & $8,380.5$ & 54.1 & 23.79 & 32.7 & 14.2 & 53.7 \\
\hline 208 & 13120000 & North Fork Big Lost River at Wild Horse, near Chilly, ID & 114.7 & $8,659.7$ & 58.1 & 29.80 & 43.1 & 22.0 & 72.1 \\
\hline 209 & 13120500 & Big Lost River at Howell Ranch, near Chilly, ID & 440.4 & $8,626.3$ & 37.9 & 26.96 & 37.8 & 17.9 & 60.8 \\
\hline 210 & 13128900 & Lower Cedar Creek above Diversion 3, near Mackay, ID & 8.4 & $9,461.0$ & 21.0 & 26.61 & 66.2 & 17.1 & 94.2 \\
\hline 211 & 13297300 & Holman Creek near Clayton, ID & 6.1 & $7,298.7$ & 69.6 & 20.81 & 36.6 & 24.9 & 61.5 \\
\hline 212 & 13297330 & Thompson Creek near Clayton, ID & 29.5 & $7,618.4$ & 68.9 & 22.60 & 47.7 & 23.5 & 85.8 \\
\hline 213 & 13297350 & Bruno Creek near Clayton, ID & 6.4 & $7,520.2$ & 66.3 & 21.74 & 40.8 & 21.2 & 68.3 \\
\hline 214 & 13297355 & Squaw Creek below Bruno Creek, near Clayton, ID & 71.6 & $7,729.2$ & 73.0 & 25.17 & 36.3 & 16.3 & 60.2 \\
\hline 215 & 13297450 & Little Boulder Creek near Clayton, ID & 18.3 & $8,951.8$ & 39.2 & 31.98 & 41.3 & 23.5 & 64.3 \\
\hline 216 & 13298000 & East Fork Salmon River near Clayton, ID & 540.2 & $8,092.5$ & 31.7 & 26.00 & 38.2 & 20.6 & 62.7 \\
\hline 217 & 13298300 & Malm Gulch near Clayton, ID & 9.3 & $7,015.7$ & 9.4 & 20.99 & 36.3 & 16.8 & 63.5 \\
\hline
\end{tabular}


Appendix A. Basin and climatic characteristics for streamflow-gaging stations in Idaho and bordering States used in regional regression analysis--Continued

\begin{tabular}{|c|c|c|c|c|c|c|c|c|c|}
\hline $\begin{array}{l}\text { Map } \\
\text { No. }\end{array}$ & $\begin{array}{c}\text { Gaging } \\
\text { station No. }\end{array}$ & Gaging station name & $\begin{array}{c}\text { DA } \\
\left(\mathbf{m i}^{2}\right)\end{array}$ & $\begin{array}{c}E \\
(f t)\end{array}$ & $\begin{array}{c}\mathbf{F} \\
\text { (percent) }\end{array}$ & $\begin{array}{c}P \\
\text { (in.) }\end{array}$ & $\begin{array}{c}\text { BS } \\
\text { (percent) }\end{array}$ & $\begin{array}{c}\text { NF30 } \\
\text { (percent) }\end{array}$ & $\begin{array}{c}\mathrm{S} 30 \\
\text { (percent) }\end{array}$ \\
\hline & & \multicolumn{8}{|c|}{ REGION 6 -- Continued } \\
\hline 218 & 13299000 & Challis Creek near Challis, ID & 84.6 & $7,780.8$ & 62.4 & 25.59 & 37.2 & 18.3 & 62.0 \\
\hline 219 & 13301700 & Morse Creek above Diversion near May, ID & 17.9 & $8,178.6$ & 45.4 & 21.25 & 51.4 & 26.7 & 87.5 \\
\hline 220 & 13301800 & Morse Creek near May, ID & 20.0 & $7,926.5$ & 40.7 & 20.24 & 47.9 & 24.1 & 80.6 \\
\hline 221 & 13302500 & Salmon River at Salmon, ID & $3,746.1$ & $7,397.5$ & 37.3 & 21.63 & 33.4 & 16.7 & 52.9 \\
\hline 222 & 13305000 & Lemhi River near Lemhi, ID & 907.1 & $7,430.9$ & 24.3 & 15.62 & 25.2 & 11.9 & 36.9 \\
\hline 223 & 13305500 & Lemhi River at Salmon, ID & $1,258.0$ & $7,108.2$ & 24.9 & 15.26 & 26.4 & 12.4 & 39.1 \\
\hline 224 & 13305700 & Dahlonega Creek at Gibbonsville, ID & 32.5 & $6,184.7$ & 90.9 & 25.32 & 45.2 & 18.8 & 86.3 \\
\hline 225 & 13305800 & Hughes Creek near North Fork, ID & 20.5 & $6,707.4$ & 83.9 & 27.88 & 41.3 & 20.7 & 75.8 \\
\hline 226 & 13306000 & North Fork Salmon River at North Fork, ID & 210.3 & $6,258.1$ & 77.8 & 22.87 & 43.6 & 23.1 & 78.0 \\
\hline 227 & 13306500 & Panther Creek near Shoup, ID & 520.7 & $7,028.2$ & 80.2 & 24.00 & 38.6 & 20.9 & 62.2 \\
\hline \multirow[t]{2}{*}{228} & 13307000 & Salmon River near Shoup, ID & $6,236.7$ & $7,154.3$ & 41.1 & 20.37 & 33.3 & 16.6 & 52.8 \\
\hline & & \multicolumn{8}{|c|}{ REGION 7a } \\
\hline 229 & 10315500 & Marys River above Hot Springs Creek near Deeth, NV & 389.8 & $6,589.8$ & 2.3 & 15.19 & 17.5 & 5.3 & 21.8 \\
\hline 230 & 10329500 & Martin Creek near Paradise Valley, NV & 176.2 & $6,210.4$ & 4.1 & 21.88 & 21.0 & 8.3 & 26.4 \\
\hline 231 & 10352500 & McDermitt Creek near Mc Dermitt, NV & 225.4 & $5,890.4$ & 1.4 & 17.00 & 17.3 & 4.3 & 17.2 \\
\hline 232 & 10353000 & East Fork Quinn River near McDermitt, NV & 137.9 & $6,117.4$ & 2.1 & 22.24 & 22.2 & 10.0 & 28.0 \\
\hline 233 & 10396000 & Donner And Blitzen River near Frenchglen, OR & 204.7 & $6,197.6$ & 22.4 & 29.07 & 16.2 & 5.5 & 15.2 \\
\hline 234 & 10406500 & Trout Creek near Denio, NV & 86.7 & $6,025.9$ & 3.9 & 16.86 & 23.1 & 9.0 & 31.2 \\
\hline 235 & 13155200 & Burns Gulch near Glenns Ferry, ID & 0.7 & $6,089.9$ & 1.3 & 25.00 & 30.7 & 1.7 & 53.2 \\
\hline 236 & 13155300 & Little Canyon Creek at Stout Crossing near Glenns Ferry, ID & 14.2 & $5,927.8$ & 3.0 & 23.47 & 25.2 & 8.3 & 36.8 \\
\hline 237 & 13161200 & Seventy Six Creek near Charleston, NV & 3.6 & $7,067.5$ & 1.3 & 24.49 & 27.4 & 6.6 & 38.9 \\
\hline 238 & 13161300 & Meadow Creek near Rowland, NV & 57.6 & $6,597.0$ & 3.6 & 19.58 & 25.7 & 11.9 & 35.2 \\
\hline 239 & 13162200 & Jarbidge River at Jarbidge, NV & 22.6 & $8,260.7$ & 37.8 & 33.79 & 48.8 & 22.7 & 85.8 \\
\hline 240 & 13162400 & Buck Creek near Jarbidge, NV & 25.8 & $7,069.6$ & 13.7 & 22.42 & 17.9 & 7.7 & 18.8 \\
\hline 241 & 13162500 & East Fork Jarbidge River near Three Creek, ID & 84.9 & $7,603.0$ & 24.5 & 24.77 & 35.3 & 16.1 & 55.2 \\
\hline 242 & 13162600 & Columbet Creek near Jarbidge, NV & 3.5 & $7,028.8$ & 8.4 & 22.15 & 16.8 & 7.1 & 14.1 \\
\hline 243 & 13169500 & Big Jacks Creek near Bruneau, ID & 243.7 & $5,170.0$ & 0.0 & 13.81 & 10.1 & 2.3 & 7.4 \\
\hline 244 & 13170000 & Little Jacks Creek near Bruneau, ID & 103.4 & $5,067.4$ & 0.1 & 14.22 & 13.2 & 3.8 & 11.5 \\
\hline 245 & 13170100 & Sugar Creek Tributary near Grasmere, ID & 4.5 & $4,856.2$ & 0.0 & 10.00 & 8.0 & 0.0 & 0.2 \\
\hline 246 & 13172200 & Fossil Creek near Oreana, ID & 16.7 & $3,879.7$ & 2.1 & 9.79 & 11.4 & 4.2 & 11.0 \\
\hline 247 & 13172666 & West Fork Reynolds Creek near Reynolds, ID & 0.4 & $6,821.4$ & 40.2 & 15.00 & 17.5 & 6.0 & 10.4 \\
\hline 248 & 13172668 & East Fork Reynolds Creek near Reynolds, ID & 0.2 & $6,810.7$ & 3.3 & 25.00 & 13.3 & 0.4 & 0.6 \\
\hline 249 & 13172680 & Reynolds Creek at Toolgate Weir near Reynolds, ID & 18.7 & $6,133.6$ & 38.4 & 21.22 & 23.0 & 11.1 & 24.9 \\
\hline 250 & 13172720 & Macks Creek near Reynolds, ID & 12.5 & $4,883.0$ & 11.1 & 13.64 & 21.1 & 7.7 & 21.6 \\
\hline 251 & 13172735 & Salmon Creek near Reynolds, ID & 13.1 & $5,001.8$ & 5.5 & 14.66 & 26.1 & 9.7 & 36.3 \\
\hline 252 & 13172740 & Reynolds Creek at Outlet Weir near Reynolds, ID & 91.8 & $5,015.7$ & 12.4 & 14.83 & 20.2 & 7.2 & 20.7 \\
\hline 253 & 13172800 & Little Squaw Creek Tributary near Marsing, ID & 1.8 & $4,447.6$ & 0.0 & 10.00 & 14.3 & 0.1 & 8.3 \\
\hline 254 & 13178000 & Jordan Creek above Lone Tree Creek, near Jordan Vallley, ID & 454.2 & $5,781.8$ & 38.9 & 26.15 & 19.5 & 5.8 & 21.8 \\
\hline
\end{tabular}


Appendix A. Basin and climatic characteristics for streamflow-gaging stations in Idaho and bordering States used in regional regression analysis--Continued

\begin{tabular}{|c|c|c|c|c|c|c|c|c|c|}
\hline $\begin{array}{l}\text { Map } \\
\text { No. }\end{array}$ & $\begin{array}{c}\text { Gaging } \\
\text { station No. }\end{array}$ & Gaging station name & $\begin{array}{c}\text { DA } \\
\left(\mathrm{mi}^{2}\right)\end{array}$ & $\begin{array}{c}E \\
(f t)\end{array}$ & $\begin{array}{c}\mathbf{F} \\
\text { (percent) }\end{array}$ & $\begin{array}{c}P \\
\text { (in.) } \\
\end{array}$ & $\begin{array}{c}\text { BS } \\
\text { (percent) }\end{array}$ & $\begin{array}{c}\text { NF30 } \\
\text { (percent) }\end{array}$ & $\begin{array}{c}\mathrm{S} 30 \\
\text { (percent) }\end{array}$ \\
\hline & & \multicolumn{8}{|c|}{ REGION 7a -- Continued } \\
\hline 255 & 13210300 & Bryans Run near Boise, ID & 9.1 & $3,605.5$ & 0.0 & 10.23 & 3.2 & 0.0 & 0.0 \\
\hline 256 & 13226500 & Bully Creek at Warmsprings near Vale, OR & 535.3 & $4,133.8$ & 0.8 & 12.26 & 17.4 & 3.7 & 15.3 \\
\hline \multicolumn{10}{|c|}{ REGION $7 b$} \\
\hline 257 & 10119000 & Little Malad River above Elkhorn Reservoir, near Malad City, & 107.1 & $6,070.2$ & 8.1 & 13.20 & 17.7 & 6.1 & 17.8 \\
\hline 258 & 10122500 & Devil Creek above Campbell Creek, near Malad City, ID & 12.5 & $5,986.6$ & 9.4 & 15.08 & 17.5 & 4.7 & 17.9 \\
\hline 259 & 10123000 & Devil Creek above Evans Dividers, near Malad City, ID & 34.0 & $5,883.8$ & 11.1 & 16.79 & 20.8 & 6.6 & 24.4 \\
\hline 260 & 10172940 & Dove Creek near Park Valley, UT & 28.7 & $6,681.4$ & 0.7 & 17.00 & 17.5 & 3.7 & 13.7 \\
\hline 261 & 13057600 & Homer Creek near Herman, ID & 26.7 & $6,477.2$ & 14.9 & 15.65 & 9.0 & 0.6 & 1.4 \\
\hline 262 & 13057940 & Willow Creek below Tex Creek near Ririe, ID & 431.4 & $6,422.9$ & 19.2 & 16.61 & 13.3 & 2.8 & 8.4 \\
\hline 263 & 13073700 & Robbers Roost Creek near McCammon, ID & 3.9 & $6,767.0$ & 41.5 & 24.88 & 42.4 & 21.8 & 77.0 \\
\hline 264 & 13075000 & Marsh Creek near McCammon, ID & 367.4 & $5,587.7$ & 9.0 & 14.30 & 16.8 & 6.4 & 20.2 \\
\hline 265 & 13075600 & North Fork Pocatello Creek near Pocatello, ID & 14.0 & $5,756.2$ & 7.7 & 15.00 & 21.2 & 8.0 & 17.3 \\
\hline 266 & 13076200 & Bannock Creek near Pocatello, ID & 407.3 & $5,545.4$ & 7.3 & 16.28 & 16.4 & 6.9 & 18.7 \\
\hline 267 & 13077700 & George Creek near Yost, UT & 7.9 & $8,483.9$ & 40.7 & 23.66 & 32.3 & 29.7 & 51.8 \\
\hline 268 & 13079200 & Cassia Creek near Elba, ID & 81.2 & $6,460.8$ & 16.3 & 17.39 & 23.5 & 12.2 & 33.0 \\
\hline 269 & 13083000 & Trapper Creek near Oakley, ID & 52.4 & $6,339.4$ & 6.2 & 17.39 & 28.1 & 14.4 & 41.3 \\
\hline 270 & 13092000 & Rock Creek near Rock Creek, ID & 81.6 & $6,350.2$ & 9.4 & 14.46 & 31.6 & 13.8 & 48.7 \\
\hline 271 & 13145700 & Schooler Screek near Gooding, ID & 2.1 & $5,624.1$ & 0.0 & 10.00 & 10.1 & 0.2 & 2.0 \\
\hline 272 & 13147300 & Muldoon Creek near Garfield Guard Station, ID & 12.3 & $8,395.8$ & 30.8 & 25.00 & 47.4 & 12.7 & 79.0 \\
\hline 273 & 13148000 & Little Wood River at Campbell Ranch near Carey, ID & 263.4 & $7,045.9$ & 17.9 & 22.03 & 34.9 & 13.5 & 57.5 \\
\hline \multicolumn{10}{|c|}{ REGION 8} \\
\hline 274 & 06037500 & Madison River near West Yellowstone, MT & 434.9 & $7,900.0$ & 93.9 & 42.30 & 11.3 & 2.4 & 7.9 \\
\hline 275 & 09223000 & Hams Fork below Pole Creek near Frontier, WY & 128.6 & $8,466.6$ & 72.8 & 31.97 & 20.4 & 5.0 & 19.5 \\
\hline 276 & 10015700 & $\begin{array}{l}\text { Sulphur Creek above reservoir, below La Chapelle Creek, } \\
\text { near Evanston, WY }\end{array}$ & 58.5 & $7,971.5$ & 25.4 & 21.62 & 9.6 & 0.3 & 1.2 \\
\hline 277 & 10040000 & Thomas Fork near Geneva, ID & 45.4 & $7,243.6$ & 24.8 & 23.80 & 26.5 & 8.1 & 36.9 \\
\hline 278 & 10040500 & Salt Creek near Geneva, ID & 38.1 & $7,448.4$ & 51.3 & 26.84 & 27.9 & 8.3 & 42.9 \\
\hline 279 & 10041000 & Thomas Fork near Wyoming-Idaho State Line, WY & 113.8 & $7,330.7$ & 36.5 & 25.13 & 27.4 & 8.7 & 40.7 \\
\hline 280 & 10047500 & Montpelier Creek at Irrigators Weir, near Montpelier, ID & 50.6 & $7,360.5$ & 28.5 & 21.49 & 32.0 & 14.1 & 52.6 \\
\hline 281 & 10058600 & Bloomington Creek at Bloomington, ID & 24.3 & $7,684.3$ & 37.6 & 35.10 & 27.4 & 15.7 & 40.5 \\
\hline 282 & 10069000 & Georgetown Creek near Georgetown, ID & 21.9 & $7,824.2$ & 55.4 & 26.14 & 40.6 & 19.6 & 70.8 \\
\hline 283 & 10072800 & Eightmile Creek near Soda Springs, ID & 17.2 & $7,598.6$ & 75.5 & 30.73 & 29.9 & 15.1 & 47.3 \\
\hline 284 & 10076400 & Soda Creek at Fivemile Meadows, near Soda Springs, ID & 42.5 & $6,193.0$ & 1.2 & 18.42 & 5.1 & 0.8 & 3.4 \\
\hline 285 & 10077000 & Soda Creek near Soda Springs, ID & 50.9 & $6,184.9$ & 2.3 & 18.19 & 6.1 & 1.7 & 5.5 \\
\hline 286 & 10084500 & Cottonwood Creek near Cleveland, ID & 62.4 & $6,720.9$ & 40.4 & 23.61 & 20.9 & 5.8 & 21.8 \\
\hline 287 & 10089500 & Mink Creek near Mink Creek, ID & 68.4 & $6,534.7$ & 40.0 & 26.57 & 28.6 & 14.9 & 42.4 \\
\hline 288 & 10090800 & Battle Creek Tributary near Treasureton, ID & 4.7 & $5,837.2$ & 2.2 & 15.10 & 17.4 & 4.8 & 10.3 \\
\hline 289 & 10093000 & Cub River near Preston, ID & 30.4 & $7,384.3$ & 53.7 & 36.05 & 31.3 & 13.9 & 49.4 \\
\hline
\end{tabular}


Appendix A. Basin and climatic characteristics for streamflow-gaging stations in Idaho and bordering States used in regional regression analysis--Continued

\begin{tabular}{|c|c|c|c|c|c|c|c|c|c|}
\hline $\begin{array}{l}\text { Map } \\
\text { No. }\end{array}$ & $\begin{array}{c}\text { Gaging } \\
\text { station No. }\end{array}$ & Gaging station name & $\begin{array}{c}\text { DA } \\
\left(\mathrm{mi}^{2}\right)\end{array}$ & $\begin{array}{c}E \\
(\mathrm{ft})\end{array}$ & $\begin{array}{c}\mathbf{F} \\
\text { (percent) }\end{array}$ & $\begin{array}{c}\mathbf{P} \\
\text { (in.) } \\
\end{array}$ & $\begin{array}{c}\text { BS } \\
\text { (percent) }\end{array}$ & $\begin{array}{c}\text { NF30 } \\
\text { (percent) }\end{array}$ & $\begin{array}{c}\mathrm{S} 30 \\
\text { (percent) }\end{array}$ \\
\hline & & \multicolumn{8}{|c|}{ REGION 8 -- Continued } \\
\hline 290 & 10096000 & Cub River above Maple Creek near Franklin, ID & 23.2 & $5,691.9$ & 2.5 & 14.22 & 19.8 & 5.1 & 18.0 \\
\hline 291 & 10099000 & High Creek near Richmond, UT & 16.3 & $7,655.4$ & 62.2 & 40.94 & 49.4 & 30.6 & 86.6 \\
\hline 292 & 13010000 & Snake River at south boundary of Y.N.P., WY & 477.4 & $7,232.2$ & 82.6 & 47.68 & 15.9 & 5.6 & 14.8 \\
\hline 293 & 13010065 & Snake River above Jackson Lake at Flagg Ranch, WY & 502.5 & $8,199.4$ & 82.8 & 47.42 & 15.8 & 5.5 & 14.7 \\
\hline 294 & 13011500 & Pacific Creek at Moran, WY & 162.7 & $8,134.7$ & 72.4 & 36.25 & 20.3 & 6.1 & 20.8 \\
\hline 295 & 13011800 & Blackrock Creek Tributary near Moran, WY & 2.5 & $9,690.1$ & 39.2 & 39.20 & 22.8 & 2.8 & 23.2 \\
\hline 296 & 13011900 & Buffalo Fork above Lava Creek near Moran, WY & 330.1 & $8,951.0$ & 59.7 & 37.05 & 27.0 & 12.1 & 33.9 \\
\hline 297 & 13012000 & Buffalo Fork near Moran, WY & 370.2 & $8,815.8$ & 60.2 & 35.58 & 26.3 & 11.5 & 32.8 \\
\hline 298 & 13014500 & Gros Ventre River at Kelly, WY & 608.0 & $8,863.0$ & 62.6 & 31.62 & 23.3 & 8.3 & 26.9 \\
\hline 299 & 13015000 & Gros Ventre River at Zenith, WY & 627.2 & $8,792.9$ & 61.5 & 31.27 & 22.8 & 8.1 & 26.3 \\
\hline 300 & 13018300 & Cache Creek near Jackson, WY & 10.7 & $8,291.9$ & 75.7 & 34.72 & 40.3 & 21.0 & 71.2 \\
\hline 301 & 13019210 & Rim Draw near Bondurant, WY & 4.7 & $8,030.8$ & 94.9 & 26.96 & 26.5 & 7.6 & 38.8 \\
\hline 302 & 13019220 & Sour Moose Creek near Bondurant, WY & 2.8 & $7,773.4$ & 82.4 & 25.46 & 22.8 & 6.7 & 25.2 \\
\hline 303 & 13019400 & Cliff Creek near Bondurant, WY & 58.2 & $8,078.6$ & 71.6 & 28.09 & 35.1 & 17.7 & 55.5 \\
\hline 304 & 13019438 & Little Granite Creek at mouth near Bondurant, WY & 82.7 & $8,559.5$ & 54.5 & 31.02 & 38.6 & 16.1 & 60.8 \\
\hline 305 & 13019500 & Hoback River near Jackson, WY & 561.3 & $7,961.5$ & 60.9 & 26.68 & 30.3 & 12.7 & 42.6 \\
\hline 306 & 13020000 & Fall Creek near Jackson, WY & 46.9 & $7,459.6$ & 65.6 & 28.89 & 32.7 & 18.4 & 50.5 \\
\hline 307 & 13021000 & Cabin Creek near Jackson, WY & 9.0 & $7,274.0$ & 72.5 & 23.64 & 35.6 & 26.5 & 64.7 \\
\hline 308 & 13022550 & Red Creek near Alpine, WY & 3.9 & $7,938.7$ & 38.8 & 30.63 & 53.6 & 7.7 & 88.7 \\
\hline 309 & 13023000 & Greys River above reservoir, near Alpine, WY & 448.8 & $8,105.3$ & 72.2 & 34.91 & 35.1 & 16.7 & 54.5 \\
\hline 310 & 13023800 & Fish Creek near Smoot, WY & 3.2 & $7,568.8$ & 68.8 & 27.87 & 18.7 & 3.2 & 11.9 \\
\hline 311 & 13024000 & Salt River near Smoot, WY & 48.2 & $8,010.1$ & 73.4 & 32.89 & 28.0 & 9.3 & 40.5 \\
\hline 312 & 13024500 & Cottonwood Creek near Smoot, WY & 25.7 & $8,647.5$ & 73.4 & 39.48 & 45.1 & 21.6 & 81.3 \\
\hline 313 & 13025000 & Swift Creek near Afton, WY & 27.7 & $8,496.0$ & 72.3 & 39.33 & 49.3 & 20.7 & 84.9 \\
\hline 314 & 13025500 & Crow Creek near Fairview, WY & 113.8 & $8,441.5$ & 34.5 & 29.44 & 24.9 & 9.9 & 33.2 \\
\hline 315 & 13027000 & Strawberry Creek near Bedford, WY & 20.1 & $8,469.4$ & 54.0 & 40.81 & 49.7 & 20.1 & 80.7 \\
\hline 316 & 13027200 & Bear Canyon near Freedom, WY & 3.3 & $7,087.4$ & 50.8 & 28.44 & 27.9 & 4.5 & 40.2 \\
\hline 317 & 13029500 & McCoy Creek above reservoir near Alpine, WY & 108.1 & $7,017.8$ & 59.3 & 26.69 & 27.5 & 12.4 & 40.4 \\
\hline 318 & 13030000 & Indian Creek above reservoir near Alpine, WY & 36.5 & $7,962.0$ & 46.8 & 31.08 & 51.5 & 25.2 & 83.1 \\
\hline 319 & 13030500 & Elk Creek above reservoir near Irwin, ID & 58.5 & $7,908.8$ & 59.5 & 34.15 & 49.8 & 26.6 & 81.4 \\
\hline 320 & 13032000 & Bear Creek above reservoir near Irwin, ID & 78.3 & $7,187.5$ & 56.1 & 26.74 & 38.8 & 22.6 & 69.7 \\
\hline 321 & 13038900 & Targhee Creek near Macks Inn, ID & 20.9 & $8,273.4$ & 57.8 & 30.06 & 34.6 & 11.8 & 49.3 \\
\hline 322 & 13044500 & Warm River at Warm River, ID & 131.1 & $6,675.6$ & 69.3 & 31.78 & 9.1 & 1.5 & 5.5 \\
\hline 323 & 13045500 & Robinson Creek at Warm River, ID & 123.7 & $6,418.3$ & 65.4 & 35.26 & 10.6 & 1.3 & 5.4 \\
\hline 324 & 13046680 & Boundary Creek near Bechler Ranger Station Y.N.P., ID & 85.4 & $7,912.5$ & 87.7 & 56.03 & 6.9 & 0.2 & 3.3 \\
\hline 325 & 13047500 & Falls River near Squirrel, ID & 333.6 & $7,540.3$ & 83.6 & 52.87 & 11.0 & 2.4 & 7.8 \\
\hline 326 & 13049500 & Falls River near Chester, ID & 512.9 & $6,974.2$ & 63.3 & 42.64 & 9.9 & 2.1 & 6.4 \\
\hline 327 & 13050700 & Mail Cabin Creek near Victor, ID & 3.0 & $8,287.6$ & 77.8 & 40.89 & 45.1 & 37.0 & 86.6 \\
\hline
\end{tabular}


APPENDIX A. Basin and climatic characteristics for streamflow-gaging stations in Idaho and bordering States used in regional regression analysis--Continued

\begin{tabular}{|c|c|c|c|c|c|c|c|c|c|}
\hline $\begin{array}{l}\text { Map } \\
\text { No. }\end{array}$ & $\begin{array}{c}\text { Gaging } \\
\text { station No. }\end{array}$ & Gaging station name & $\begin{array}{c}\text { DA } \\
\left(\mathrm{mi}^{2}\right)\end{array}$ & $\begin{array}{c}E \\
(f t)\end{array}$ & $\begin{array}{c}\mathbf{F} \\
\text { (percent) }\end{array}$ & $\begin{array}{c}\mathbf{P} \\
\text { (in.) }\end{array}$ & $\begin{array}{c}\text { BS } \\
\text { (percent) }\end{array}$ & $\begin{array}{c}\text { NF30 } \\
\text { (percent) }\end{array}$ & $\begin{array}{c}\text { S30 } \\
\text { (percent) }\end{array}$ \\
\hline & & \multicolumn{8}{|c|}{ REGION 8 -- Continued } \\
\hline 328 & 13050800 & Moose Creek near Victor, ID & 21.8 & $8,499.6$ & 65.1 & 54.17 & 41.7 & 23.4 & 68.3 \\
\hline 329 & 13052200 & Teton River above South Leigh Creek, near Driggs, ID & 341.4 & $7,302.9$ & 39.7 & 31.73 & 23.6 & 13.3 & 34.5 \\
\hline 330 & 13054000 & Teton River near Tetonia, ID & 479.2 & $7,200.1$ & 38.2 & 30.33 & 21.5 & 11.5 & 30.0 \\
\hline 331 & 13054400 & Milk Creek near Tetonia, ID & 17.5 & $6,551.9$ & 15.7 & 16.55 & 9.2 & 0.4 & 1.8 \\
\hline 332 & 13055000 & Teton River near St. Anthony, ID & 874.8 & $6,920.9$ & 36.1 & 27.65 & 19.0 & 9.1 & 24.3 \\
\hline 333 & 13062700 & Angus Creek near Henry, ID & 14.3 & $6,881.2$ & 28.3 & 20.00 & 18.0 & 5.3 & 18.2 \\
\hline
\end{tabular}


Appendix B. Peak flows at selected recurrence intervals for streamflow-gaging stations in Idaho and bordering States used in regional regression analysis

[ND, not determined because peak flow is below base flow]

\begin{tabular}{|c|c|c|c|c|}
\hline \multicolumn{3}{|c|}{$\begin{array}{l}\text { Peak flow, in cubic feet per } \\
\text { second, for given recurrence } \\
\text { intervals, in years }\end{array}$} & \multirow[b]{2}{*}{ Period of known peak flows } & \multirow{2}{*}{$\begin{array}{c}\text { Number } \\
\text { of years } \\
\text { of known } \\
\text { peak }\end{array}$} \\
\hline 1.5 & 2 & 2.33 & & \\
\hline \multicolumn{5}{|c|}{ REGION 1} \\
\hline 1,050 & 1,240 & 1,330 & $1929-80$ & 50 \\
\hline 29 & 42 & 49 & $1928-31,33,35-38,74$ & 11 \\
\hline 127 & 154 & 167 & $1961-80$ & 19 \\
\hline 773 & 929 & 1,000 & $1928-74$ & 45 \\
\hline 407 & 524 & 583 & $1928-34,72-79$ & 15 \\
\hline 298 & 338 & 356 & $1959-81$ & 23 \\
\hline 524 & 602 & 637 & $1928-59$ & 32 \\
\hline 1,680 & 1,930 & 2,040 & $1928-71$ & 43 \\
\hline 29 & 42 & 51 & $1962-81$ & 20 \\
\hline 2,880 & 3,140 & 3,260 & 1989-99 & 11 \\
\hline 2,240 & 2,580 & 2,740 & $1959-82$ & 24 \\
\hline 33 & 36 & 38 & $1961-71$ & 11 \\
\hline 4,240 & 4,830 & 5,100 & $1913-48$ & 35 \\
\hline 51 & 64 & 70 & $1962-71$ & 18 \\
\hline 405 & 506 & 556 & $1951-97$ & 47 \\
\hline 324 & 298 & 328 & $1940-86$ & 47 \\
\hline 881 & 1,150 & 1,280 & $1923-97$ & 75 \\
\hline 99 & 109 & 114 & $1949-79$ & 31 \\
\hline 117 & 137 & 146 & $1962-75$ & 14 \\
\hline 14 & 22 & 27 & $1950,62-75$ & 15 \\
\hline 1,030 & 1,290 & 1,410 & $1929-32,47-97$ & 55 \\
\hline \multicolumn{5}{|c|}{ REGION 2} \\
\hline 530 & 642 & 696 & $1933,37-44,48,54,59-69,74$ & 23 \\
\hline 191 & 226 & 243 & $1960-92$ & 33 \\
\hline 1,850 & 2,170 & 2,330 & $1945-57,74,83-96$ & 28 \\
\hline 22 & 27 & 30 & $1960-74$ & 15 \\
\hline 109 & 128 & 137 & $1960-78$ & 19 \\
\hline 141 & 170 & 184 & $1960-74$ & 15 \\
\hline 1,100 & 1,270 & 1,350 & $1899,1948,58-59,61-64,66-67$ & 10 \\
\hline 123 & 148 & 160 & $1958-73$ & 16 \\
\hline 572 & 627 & 651 & $1947-69,72$ & 24 \\
\hline 89 & 109 & 119 & $1958-73$ & 16 \\
\hline 701 & 810 & 860 & $1948-53,58-73$ & 22 \\
\hline 1,470 & 1,670 & 1,760 & $1951-60,72,74$ & 12 \\
\hline 50 & 67 & 76 & $1961-79,82$ & 20 \\
\hline 31 & 39 & 43 & $1961-75,79$ & 16 \\
\hline 3,420 & 4,410 & 4,900 & $1911-17,34,48,54,59-75$ & 27 \\
\hline 154 & 180 & 192 & $1960-74$ & 15 \\
\hline 1,830 & 2,310 & 2,550 & $1948,56-97$ & 43 \\
\hline 1,310 & 1,590 & 1,720 & $1956-97$ & 42 \\
\hline 4,840 & 6,040 & 6,620 & $1951-97$ & 47 \\
\hline 12,000 & 15,100 & 16,600 & 1940-97 & 58 \\
\hline 88 & 104 & 111 & $1961-71,73-80$ & 19 \\
\hline 281 & 376 & 425 & $1968-97$ & 30 \\
\hline 1,390 & 1,660 & 1,790 & $1968-88$ & 21 \\
\hline 56 & 73 & 81 & $1962-71$ & 10 \\
\hline 1,500 & 1,940 & 2,160 & $1987-99$ & 13 \\
\hline 2,820 & 3,660 & 4,080 & $1988-97$ & 10 \\
\hline
\end{tabular}


Appendix B. Peak flows at selected recurrence intervals for streamflow-gaging stations in Idaho and bordering States used in regional regression analysis--Continued

\begin{tabular}{|c|c|c|c|c|}
\hline \multicolumn{3}{|c|}{$\begin{array}{l}\text { Peak flow, in cubic feet per } \\
\text { second, for given recurrence } \\
\text { intervals, in years }\end{array}$} & \multirow[b]{2}{*}{ Period of known peak flows } & \multirow{2}{*}{$\begin{array}{c}\text { Number } \\
\text { of years } \\
\text { of known } \\
\text { peak }\end{array}$} \\
\hline 1.5 & 2 & 2.33 & & \\
\hline \multicolumn{5}{|c|}{ REGION 2--Continued } \\
\hline 15,200 & 18,800 & 20,600 & $1911-97$ & 66 \\
\hline 476 & 587 & 641 & 1967-71, 73-81 & 14 \\
\hline 12,900 & 15,500 & 16,800 & $1911-12,21-97$ & 79 \\
\hline 2,350 & 3,060 & 3,420 & 1966-97 & 32 \\
\hline 3,750 & 4,780 & 5,290 & $1912,21-66$ & 45 \\
\hline 97 & 113 & 121 & $1961-71,74$ & 12 \\
\hline 56 & 67 & 73 & 1961-81 & 21 \\
\hline 239 & 319 & 360 & 1948-97 & 43 \\
\hline 22,400 & 25,500 & 27,000 & $1911,30-99$ & 71 \\
\hline 57 & 73 & 81 & 1962-71 & 10 \\
\hline 67 & 78 & 84 & $1962-71$ & 10 \\
\hline 212 & 267 & 294 & $1962-71$ & 10 \\
\hline 1,570 & 1,710 & 1,770 & 1958-67 & 10 \\
\hline 16,400 & 18,700 & 19,800 & $1911-12,30-99$ & 72 \\
\hline 14,600 & 16,300 & 17,100 & 1945-69 & 25 \\
\hline 16,300 & 18,800 & 19,900 & 1967-97 & 33 \\
\hline 46 & 58 & 64 & $1960-71,73-79$ & 19 \\
\hline 539 & 644 & 694 & $1960-71$ & 12 \\
\hline \multicolumn{5}{|c|}{ REGION 3} \\
\hline 35 & 55 & 66 & $1961-70,72-76$ & 16 \\
\hline 22 & 25 & 27 & $1962-76$ & 15 \\
\hline 11 & 18 & 22 & $1954-73$ & 20 \\
\hline 4,950 & 6,510 & 7,270 & 1948-97 & 50 \\
\hline 276 & 405 & 476 & $1960-82,91-96$ & 30 \\
\hline 6 & 17 & 26 & $1959-76$ & 18 \\
\hline 31 & 47 & 56 & $1961-65,67-71,74-81$ & 18 \\
\hline 5,130 & 6,210 & 6,720 & $1945-71$ & 26 \\
\hline 527 & 816 & 977 & $1975-97$ & 23 \\
\hline 55 & 78 & 158 & $1963-77$ & 15 \\
\hline 452 & 651 & 757 & $1964-78$ & 15 \\
\hline 1,010 & 1,490 & 1,750 & $1915-17,29-31,59-90,95-97$ & 41 \\
\hline 46 & 56 & 61 & $1961-71$ & 11 \\
\hline 631 & 799 & 882 & $1961-71,74-81$ & 19 \\
\hline 2,810 & 3,580 & 3,970 & $1915-19,67-97$ & 36 \\
\hline 3,690 & 4,530 & 4,930 & $1956-79$ & 24 \\
\hline 10 & 12 & 13 & $1956-59,61,63-64,66-71$ & 13 \\
\hline 261 & 331 & 365 & $1979-97$ & 19 \\
\hline 797 & 1,040 & 1,170 & $1934-42,48,59-81$ & 33 \\
\hline 316 & 396 & 435 & $1935-40,48,60-79$ & 27 \\
\hline 4,420 & 5,600 & 6,180 & $1963-95$ & 33 \\
\hline 1,310 & 1,840 & 2,120 & $1962-79$ & 18 \\
\hline 646 & 865 & 976 & 1954-79 & 26 \\
\hline 359 & 522 & 610 & $1949-53,55-67$ & 18 \\
\hline 657 & 858 & 959 & $1944-51,56-68$ & 21 \\
\hline 2,190 & 2,770 & 3,060 & $1906-89$ & 84 \\
\hline \multicolumn{5}{|c|}{ REGION 4} \\
\hline 63 & 91 & 107 & 1914-18, 39-43, 55 & 11 \\
\hline 10 & 13 & 15 & 1939-41, 51-71 & 24 \\
\hline 1,220 & 1,650 & 1,860 & 1951-97 & 47 \\
\hline
\end{tabular}


Appendix B. Peak flows at selected recurrence intervals for streamflow-gaging stations in Idaho and bordering States used in regional regression analysis--Continued

\begin{tabular}{|c|c|c|c|c|}
\hline \multicolumn{3}{|c|}{$\begin{array}{l}\text { Peak flow, in cubic feet per } \\
\text { second, for given recurrence } \\
\text { intervals, in years }\end{array}$} & \multirow[b]{2}{*}{ Period of known peak flows } & \multirow{2}{*}{$\begin{array}{c}\text { Number } \\
\text { of years } \\
\text { of known } \\
\text { peak }\end{array}$} \\
\hline 1.5 & 2 & 2.33 & & \\
\hline \multicolumn{5}{|c|}{ REGION 4--Continued } \\
\hline 47 & 62 & 70 & $1951-71$ & 21 \\
\hline 1,510 & 1,930 & 2,130 & 1916-54 & 39 \\
\hline 32 & 51 & 62 & $1955-59,61-71$ & 16 \\
\hline 58 & 94 & 114 & $1955-68$ & 14 \\
\hline 647 & 882 & 1,000 & $1904-82,84-94$ & 90 \\
\hline 61 & 78 & 87 & $1961-71,73-80$ & 19 \\
\hline 753 & 938 & 1,030 & $1957,62-82,97$ & 23 \\
\hline 55 & 92 & 114 & $1962-71$ & 10 \\
\hline 32 & 39 & 42 & $1960-77$ & 18 \\
\hline 395 & 484 & 527 & $1937-71,74-75,97$ & 38 \\
\hline 51 & 55 & 57 & $1933-35,37-43$ & 10 \\
\hline 793 & 991 & 1,090 & $1939-49,56$ & 12 \\
\hline 2,390 & 2,910 & 3,160 & $1937-41,43-53,56$ & 17 \\
\hline 668 & 817 & 880 & $1911-13,20-21,37-49,56,81-82,85-88,97$ & 26 \\
\hline 3,840 & 4,770 & 5,220 & $1939-97$ & 59 \\
\hline 210 & 266 & 293 & $1939-62,97$ & 25 \\
\hline 601 & 729 & 791 & $1923-27,38-71,97$ & 40 \\
\hline 7,600 & 9,720 & 10,800 & $1890-91,1895-1904,11-14,53-97$ & 61 \\
\hline 337 & 420 & 461 & $1911-13,19337-65$ & 32 \\
\hline 53 & 67 & 73 & $1962-71$ & 10 \\
\hline 583 & 686 & 734 & $1967-80$ & 16 \\
\hline 59 & 73 & 79 & $1964-81$ & 18 \\
\hline 568 & 708 & 775 & $1904-16,20-25,27-68$ & 61 \\
\hline 1,760 & 2,020 & 2,140 & $1958-97$ & 40 \\
\hline 71 & 89 & 98 & $1964-65,67-81$ & 17 \\
\hline 66 & 91 & 103 & $1962-71$ & 10 \\
\hline 692 & 903 & 1,010 & $1979-96$ & 18 \\
\hline 2,010 & 2,570 & 2,840 & $1967-96$ & 30 \\
\hline 1,510 & 1,640 & 1,700 & $1945-53$ & 9 \\
\hline 60 & 72 & 78 & $1965-75$ & 11 \\
\hline 167 & 199 & 214 & $1937-38,46-59,62-71$ & 26 \\
\hline 4,160 & 4,900 & 5,240 & $1948,51-99$ & 48 \\
\hline 110 & 138 & 151 & 1960-71 & 12 \\
\hline 52,200 & 61,600 & 66,000 & $1894,1911-99$ & 88 \\
\hline 66 & 98 & 115 & $1961-72$ & 12 \\
\hline 2,670 & 3,260 & 3,540 & $1904-09,11-15,18-23,26-89$ & 81 \\
\hline 640 & 749 & 800 & $1912,15,18-19,26,97$ & 75 \\
\hline 348 & 405 & 431 & $1938-50$ & 13 \\
\hline 459 & 540 & 578 & $1915,24-78$ & 56 \\
\hline 1,420 & 1,580 & 1,650 & $1913,26-91,95-97$ & 70 \\
\hline 801 & 923 & 979 & $1915,24-85,95-97$ & 66 \\
\hline 2,700 & 3,110 & 3,290 & $1913,66-97$ & 33 \\
\hline 71 & 90 & 99 & $1962-71$ & 10 \\
\hline 1,660 & 1,930 & 2,050 & $1945-74$ & 30 \\
\hline 74 & 91 & 98 & $1962-81$ & 16 \\
\hline 4,330 & 5,000 & 5,310 & $1911-20,23-63$ & 51 \\
\hline 159 & 186 & 198 & 1961-71 & 11 \\
\hline 5,360 & 6,560 & 7,120 & $1964-99$ & 36 \\
\hline
\end{tabular}


Appendix B. Peak flows at selected recurrence intervals for streamflow-gaging stations in Idaho and bordering States used in regional regression analysis--Continued

\begin{tabular}{|c|c|c|c|c|}
\hline \multicolumn{3}{|c|}{$\begin{array}{l}\text { Peak flow, in cubic feet per } \\
\text { second, for given recurrence } \\
\text { intervals, in years }\end{array}$} & \multirow[b]{2}{*}{ Period of known peak flows } & \multirow{2}{*}{$\begin{array}{c}\text { Number } \\
\text { of years } \\
\text { of known } \\
\text { peak }\end{array}$} \\
\hline 1.5 & 2 & 2.33 & & \\
\hline \multicolumn{5}{|c|}{ REGION 4--Continued } \\
\hline 46,500 & 53,000 & 55,900 & $1911-65$ & 55 \\
\hline 1,710 & 2,140 & 2,340 & 1980-99 & 20 \\
\hline 104 & 123 & 133 & $1962-81$ & 19 \\
\hline 74 & 109 & 127 & $1962-71,74-81$ & 18 \\
\hline 47,600 & 54,200 & 57,100 & $1931-33,35-38,65-99$ & 42 \\
\hline 637 & 776 & 844 & $1903,07,09-16,32-91$ & 70 \\
\hline 385 & 489 & 541 & $1930,33-69$ & 38 \\
\hline 686 & 890 & 994 & $1914-17,40-97$ & 62 \\
\hline 240 & 317 & 356 & $1940-42,44-71$ & 31 \\
\hline \multicolumn{5}{|c|}{ REGION 5} \\
\hline 1,950 & 2,340 & 2,520 & $1956-73$ & 18 \\
\hline 572 & 659 & 699 & $1948-54,58-79$ & 29 \\
\hline 275 & 342 & 373 & $1920,22-24,38-73$ & 40 \\
\hline 41 & 51 & 55 & $1958-73$ & 16 \\
\hline 139 & 170 & 184 & $1962-71$ & 10 \\
\hline 762 & 905 & 972 & $1948-71$ & 24 \\
\hline 27 & 40 & 47 & $1962-71$ & 10 \\
\hline 427 & 495 & 526 & $1941-58$ & 18 \\
\hline 1,800 & 2,290 & 2,520 & $1915-97$ & 83 \\
\hline 1,230 & 1,660 & 1,880 & $1912-96$ & 85 \\
\hline 42 & 54 & 60 & $1961-72$ & 11 \\
\hline 279 & 332 & 357 & $1958,63-71,73-76,78-80$ & 17 \\
\hline 84 & 102 & 111 & $1962-71$ & 10 \\
\hline 5,520 & 6,610 & 7,120 & $1871-72,1911-99$ & 91 \\
\hline 3,670 & 4,400 & 4,730 & $1945-97$ & 53 \\
\hline 536 & 655 & 712 & $1946-56$ & 11 \\
\hline 439 & 513 & 548 & 1945-56 & 12 \\
\hline 123 & 151 & 165 & $1962-71,73-80$ & 18 \\
\hline 3,620 & 4,230 & 4,510 & 1941-99 & 59 \\
\hline 116 & 148 & 164 & $1962-71$ & 10 \\
\hline 27 & 35 & 38 & $1962-71$ & 10 \\
\hline 309 & 346 & 363 & $1962-71$ & 10 \\
\hline 1,160 & 1,340 & 1,430 & $1946-97$ & 52 \\
\hline 1,080 & 1,280 & 1,370 & 1926-45 & 20 \\
\hline 71 & 89 & 97 & $1962-71,73-80$ & 18 \\
\hline 125 & 143 & 151 & 1963-71 & 9 \\
\hline 460 & 517 & 542 & $1941-52$ & 12 \\
\hline 436 & 482 & 503 & $1941-52$ & 12 \\
\hline 848 & 1,000 & 1,070 & $1911-13,21-74,93-99$ & 63 \\
\hline 2,620 & 3,070 & 3,270 & $1926-60,74$ & 36 \\
\hline 1,180 & 1,470 & 1,610 & $1921-49,74$ & 29 \\
\hline 4,180 & 4,970 & 5,330 & 1922-91 & 70 \\
\hline 24 & 33 & 38 & 1963-72 & 10 \\
\hline 1,420 & 1,660 & 1,760 & $1929-72,74$ & 45 \\
\hline 1,800 & 2,110 & 2,250 & $1922-60$ & 39 \\
\hline 7,390 & 8,870 & 9,570 & $1973-81$ & 9 \\
\hline 3,300 & 3,780 & 3,990 & $1945-58$ & 14 \\
\hline 893 & 1,030 & 1,090 & $1929,31-60$ & 31 \\
\hline 2,800 & 3,330 & 3,580 & 1967-99 & 29 \\
\hline
\end{tabular}


31

Appendix B. Peak flows at selected recurrence intervals for streamflow-gaging stations in Idaho and bordering States used in regional regression analysis--Continued

\begin{tabular}{|c|c|c|c|c|}
\hline \multicolumn{3}{|c|}{$\begin{array}{l}\text { Peak flow, in cubic feet per } \\
\text { second, for given recurrence } \\
\text { intervals, in years }\end{array}$} & \multirow[b]{2}{*}{ Period of known peak flows } & \multirow{2}{*}{$\begin{array}{c}\text { Number } \\
\text { of years } \\
\text { of known } \\
\text { peak }\end{array}$} \\
\hline 1.5 & 2 & 2.33 & & \\
\hline \multicolumn{5}{|c|}{ REGION 5--Continued } \\
\hline 143 & 173 & 188 & $1929-42,83-97$ & 29 \\
\hline 293 & 352 & 380 & $1929-40$ & 12 \\
\hline 823 & 953 & 1,010 & $1929-43$ & 15 \\
\hline 2,510 & 2,930 & 3,130 & $1929-99$ & 71 \\
\hline 1,230 & 1,400 & 1,480 & $1943-52$ & 10 \\
\hline 9,880 & 11,400 & 12,100 & $1932-48$ & 13 \\
\hline 55,000 & 61,500 & 64,300 & $1945-56$ & 12 \\
\hline \multicolumn{5}{|c|}{ REGION 6} \\
\hline 262 & 331 & 365 & $1946-53,60-91$ & 40 \\
\hline 290 & 393 & 444 & $1921-32,46-53,55-58,60-73,75$ & 39 \\
\hline 822 & 968 & 1,040 & $1939-97$ & 59 \\
\hline 628 & 808 & 897 & $1937-53,69-73$ & 22 \\
\hline 336 & 454 & 513 & $1925-97$ & 73 \\
\hline 7.3 & 9.8 & 11 & $1962-71$ & 10 \\
\hline 233 & 307 & 344 & $1941-52,69-93$ & 35 \\
\hline 197 & 264 & 297 & $1921-73,83-87$ & 57 \\
\hline 109 & 135 & 147 & $1962-71$ & 10 \\
\hline 319 & 379 & 407 & $1961-73$ & 13 \\
\hline 611 & 742 & 803 & 1944-97 & 54 \\
\hline 1,780 & 2,150 & 2,320 & $1904-14,20-97$ & 89 \\
\hline 163 & 183 & 192 & $1963-73,80-84$ & 16 \\
\hline 6.7 & 8.9 & 10 & $1963-71,74$ & 10 \\
\hline 86 & 123 & 143 & 1973-97 & 25 \\
\hline 4.4 & 7.4 & 9.2 & $1971-97$ & 27 \\
\hline 178 & 252 & 291 & $1973-97$ & 25 \\
\hline 161 & 206 & 227 & 1970-86 & 17 \\
\hline 1,280 & 1,590 & 1,730 & $1929-38,73-81$ & 19 \\
\hline 49 & 85 & 107 & $1962-71$ & 10 \\
\hline 206 & 246 & 265 & $1944-63$ & 20 \\
\hline 123 & 147 & 158 & $1962-71,73-76,78-80$ & 17 \\
\hline ND & 21 & 26 & $1962-71$ & 10 \\
\hline 6,930 & 8,490 & 9,220 & $1912-16,20-97$ & 83 \\
\hline 702 & 910 & 1,010 & 1956-97 & 42 \\
\hline 747 & 988 & 1,110 & $1929-43$ & 15 \\
\hline 74 & 97 & 109 & $1962-71$ & 10 \\
\hline 116 & 139 & 150 & $1962-80$ & 19 \\
\hline 476 & 556 & 592 & 1930-39 & 10 \\
\hline 1,440 & 1,760 & 1,910 & $1945-77$ & 33 \\
\hline 11,400 & 13,500 & 14,400 & $1945-81$ & 37 \\
\hline \multicolumn{5}{|c|}{ REGION 7a } \\
\hline 273 & 375 & 429 & $1943-80,82-97$ & 54 \\
\hline 242 & 393 & 483 & $1922-27,29-33,35-97$ & 74 \\
\hline 268 & 454 & 564 & $1949-97$ & 49 \\
\hline 307 & 407 & 457 & $1949-81$ & 33 \\
\hline 1,040 & 1,380 & 1,540 & $1911-16,18-21,30,38-98$ & 72 \\
\hline 84 & 111 & 124 & $1911,22-23,25-91$ & 70 \\
\hline 3.8 & 5.7 & 6.5 & $1960-71$ & 12 \\
\hline 68 & 87 & 97 & $1961-71,73-80$ & 19 \\
\hline 15 & 23 & 27 & 1963-79 & 17 \\
\hline
\end{tabular}


Appendix B. Peak flows at selected recurrence intervals for streamflow-gaging stations in Idaho and bordering States used in regional regression analysis--Continued

\begin{tabular}{|c|c|c|c|c|}
\hline \multicolumn{3}{|c|}{$\begin{array}{l}\text { Peak flow, in cubic feet per } \\
\text { second, for given recurrence } \\
\text { intervals, in years }\end{array}$} & \multirow[b]{2}{*}{ Period of known peak flows } & \multirow{2}{*}{$\begin{array}{c}\text { Number } \\
\text { of years } \\
\text { of known } \\
\text { peak }\end{array}$} \\
\hline 1.5 & 2 & 2.33 & & \\
\hline \multicolumn{5}{|c|}{ REGION 7a--Continued } \\
\hline 127 & 188 & 221 & $1964-78$ & 15 \\
\hline 240 & 302 & 333 & 1963-78 & 16 \\
\hline 55 & 81 & 96 & $1929-32,54-71$ & 22 \\
\hline 373 & 444 & 478 & $1963-78$ & 16 \\
\hline 8.1 & 12 & 14 & $1939-49,63,66-97$ & 44 \\
\hline 81 & 165 & 219 & $1939-49$ & 11 \\
\hline 80 & 140 & 177 & $1961-71,73-80$ & 19 \\
\hline 16 & 23 & 27 & $1961-71,74-76,78-80$ & 17 \\
\hline ND & 43 & 56 & $1965-78$ & 14 \\
\hline 3.8 & 5.1 & 5.8 & $1963-93$ & 31 \\
\hline 3.2 & 4.2 & 4.6 & $1966-93$ & 28 \\
\hline 125 & 169 & 191 & $1964-90$ & 27 \\
\hline 51 & 85 & 105 & $1964-93$ & 30 \\
\hline 35 & 63 & 81 & $1963-93$ & 31 \\
\hline 184 & 322 & 404 & $1961-71,73-80$ & 19 \\
\hline 5.4 & 10 & 13 & $1946-52,55-71$ & 24 \\
\hline 1,560 & 1,960 & 2,160 & $1961-80$ & 19 \\
\hline 33 & 59 & 75 & $1904-06,10-17,22-23,38-62,64-85$ & 59 \\
\hline 862 & 1,470 & 1,820 & $1963-79$ & 17 \\
\hline \multicolumn{5}{|c|}{ REGION $7 b$} \\
\hline 74 & 109 & 129 & $1912-13,32,41-69$ & 32 \\
\hline 50 & 65 & 73 & $1939-61$ & 23 \\
\hline 100 & 120 & 129 & $1941-43,47-52$ & 9 \\
\hline 5.1 & 10 & 13 & $1959-73$ & 15 \\
\hline 165 & 208 & 228 & 1963-71 & 9 \\
\hline 595 & 787 & 883 & $1978-79,86-97$ & 14 \\
\hline 11 & 14 & 15 & 1961-71 & 11 \\
\hline 250 & 298 & 321 & $1955-97$ & 43 \\
\hline 17 & 22 & 25 & $1961-1971$ & 11 \\
\hline 154 & 214 & 246 & 1985-94 & 10 \\
\hline 56 & 69 & 75 & $1960-89$ & 30 \\
\hline 127 & 176 & 202 & $1957-67,71$ & 12 \\
\hline 39 & 50 & 56 & $1911-16,19-30,32-97$ & 84 \\
\hline 150 & 200 & 224 & $1910-13,39,44-74$ & 36 \\
\hline 17 & 23 & 26 & $1961-76,78-80$ & 19 \\
\hline 90 & 106 & 113 & 1963-71 & 9 \\
\hline 689 & 880 & 974 & $1920-26,41-58$ & 25 \\
\hline \multicolumn{5}{|c|}{ REGION 8} \\
\hline 1,210 & 1,360 & 1,430 & $1914-17,19-73,84-96$ & 70 \\
\hline 601 & 771 & 852 & $1953-98$ & 46 \\
\hline 233 & 335 & 390 & $1958-97$ & 39 \\
\hline 110 & 147 & 165 & $1940-51$ & 12 \\
\hline 119 & 165 & 188 & $1940-51$ & 12 \\
\hline 271 & 400 & 469 & $1950-92$ & 43 \\
\hline 82 & 99 & 107 & $1943-79$ & 37 \\
\hline 124 & 150 & 162 & $1961-86$ & 26 \\
\hline 43 & 50 & 53 & $1940-56$ & 17 \\
\hline 103 & 121 & 130 & $1961-86$ & 26 \\
\hline 57 & 73 & 80 & $1965-86$ & 22 \\
\hline
\end{tabular}


33

Appendix B. Peak flows at selected recurrence intervals for streamflow-gaging stations in Idaho and bordering States used in regional regression analysis--Continued

\begin{tabular}{|c|c|c|c|c|}
\hline \multicolumn{3}{|c|}{$\begin{array}{l}\text { Peak flow, in cubic feet per } \\
\text { second, for given recurrence } \\
\text { intervals, in years }\end{array}$} & \multirow[b]{2}{*}{ Period of known peak flows } & \multirow{2}{*}{$\begin{array}{c}\text { Number } \\
\text { of years } \\
\text { of known } \\
\text { peak }\end{array}$} \\
\hline 1.5 & 2 & 2.33 & & \\
\hline \multicolumn{5}{|c|}{ REGION 8--Continued } \\
\hline 161 & 187 & 198 & $1913-26$ & 14 \\
\hline 300 & 372 & 407 & $1939-86$ & 48 \\
\hline 334 & 355 & 364 & $1943-52$ & 10 \\
\hline 30 & 45 & 53 & $1961-80$ & 20 \\
\hline 536 & 591 & 616 & $1947-52,56-62,70-84,86$ & 37 \\
\hline 527 & 558 & 571 & $1940-1952$ & 13 \\
\hline 187 & 200 & 206 & $1944-52,71-72,79-89$ & 22 \\
\hline 4,960 & 5,360 & 5,530 & $1914-15,19-25$ & 9 \\
\hline 6,490 & 8,030 & 8,760 & 1984-97 & 14 \\
\hline 2,120 & 2,510 & 2,680 & $1918,45-97$ & 52 \\
\hline 35 & 41 & 44 & 1964-74 & 11 \\
\hline 3,690 & 4,080 & 4,250 & 1966-97 & 32 \\
\hline 3,800 & 4,090 & 4,210 & $1918,45-60$ & 17 \\
\hline 2,900 & 3,180 & 3,310 & $1918,45-58$ & 15 \\
\hline 2,240 & 2,700 & 2,920 & $1917,88-97$ & 12 \\
\hline 62 & 79 & 86 & 1945-97 & 53 \\
\hline 12 & 13 & 14 & $1950-92$ & 43 \\
\hline 13 & 15 & 16 & $1943-79$ & 37 \\
\hline 520 & 612 & 655 & $1961-86$ & 26 \\
\hline 213 & 292 & 333 & 1982-92 & 11 \\
\hline 3,320 & 3,750 & 3,950 & $1918,45-58$ & 15 \\
\hline 341 & 391 & 413 & $1965-86$ & 22 \\
\hline 111 & 128 & 135 & $1914-17,19-73,84-96$ & 70 \\
\hline 18 & 21 & 23 & $1953-98$ & 46 \\
\hline 2,800 & 3,290 & 3,510 & $1918,37-38,54-97$ & 47 \\
\hline 36 & 47 & 52 & $1940-51$ & 12 \\
\hline 213 & 250 & 266 & $1932-57$ & 25 \\
\hline 210 & 242 & 256 & $1933-57$ & 24 \\
\hline 453 & 505 & 528 & $1943-80$ & 38 \\
\hline 197 & 227 & 241 & $1946-49,62-67$ & 10 \\
\hline 236 & 263 & 274 & $1932-43$ & 12 \\
\hline 32 & 44 & 51 & 1961-71 & 11 \\
\hline 800 & 924 & 980 & $1954-71,74$ & 19 \\
\hline 175 & 200 & 211 & $1918,54-71$ & 19 \\
\hline 407 & 464 & 490 & $1918,1954-71$ & 19 \\
\hline 447 & 517 & 549 & $1918,34-36,54-71$ & 22 \\
\hline 227 & 258 & 272 & $1963-80$ & 18 \\
\hline 392 & 461 & 493 & $1912-14,18-32$ & 18 \\
\hline 500 & 605 & 653 & $1912-14,18-32$ & 18 \\
\hline 429 & 502 & 535 & 1984-97 & 14 \\
\hline 3,150 & 3,550 & 3,730 & $1905-09,18-97$ & 85 \\
\hline 3,120 & 3,540 & 3,730 & 1920-97 & 78 \\
\hline 33 & 38 & 41 & $1962-71$ & 10 \\
\hline 253 & 280 & 292 & $1962-71$ & 10 \\
\hline 1,260 & 1,460 & 1,550 & $1962-97$ & 36 \\
\hline 1,070 & 1,270 & 1,350 & $1930-32,34,40-57$ & 22 \\
\hline 47 & 84 & 107 & $1962-80$ & 19 \\
\hline 2,890 & 3,380 & 3,610 & $1890-93,1903-09,20-97$ & 88 \\
\hline 206 & 283 & 322 & $1963-71,74-80$ & 16 \\
\hline
\end{tabular}

1From Berenbrock (2002, table 7, p. 16-18). 
Appendix C. $\left(X^{\top} \Lambda^{-1} X\right)^{-1}$ matrices for the $T$-year $(T=1.5,2$, and 2.33) regional regression equations for Idaho

[Some numbers are in scientific notation; DA, Drainage area; E, mean basin elevation; F, percentage of forest cover in the basin; P, mean annual precipitation; NF30, percentage of north-facing slopes greater than 30 percent; BS, average basin slope; and S30, percentage of slopes greater than 30 percent]

\section{$\left(\mathbf{X}^{\top} \Lambda^{-1} \mathbf{X}\right)^{-1}$ matrix}

\section{REGION 1}

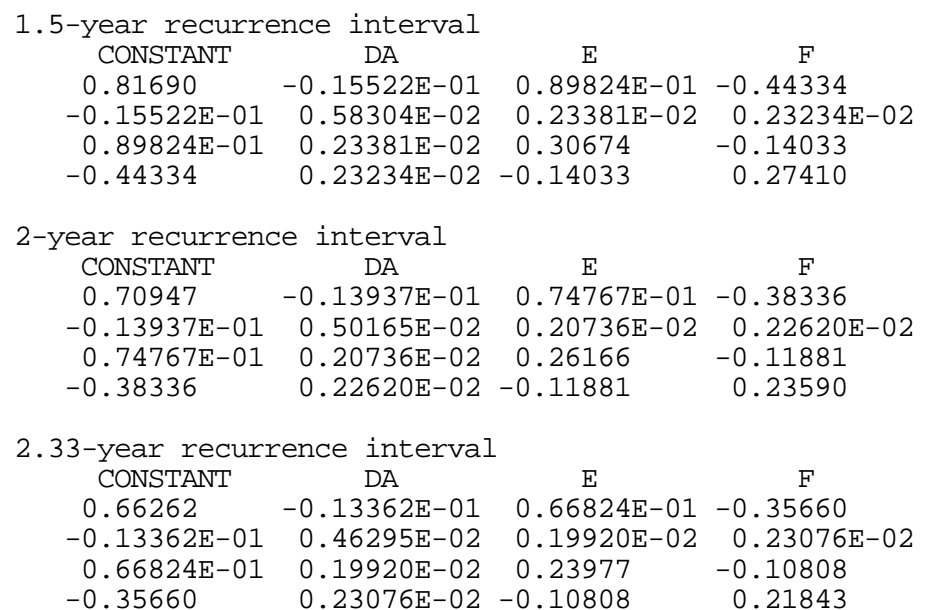

\section{REGION 2}

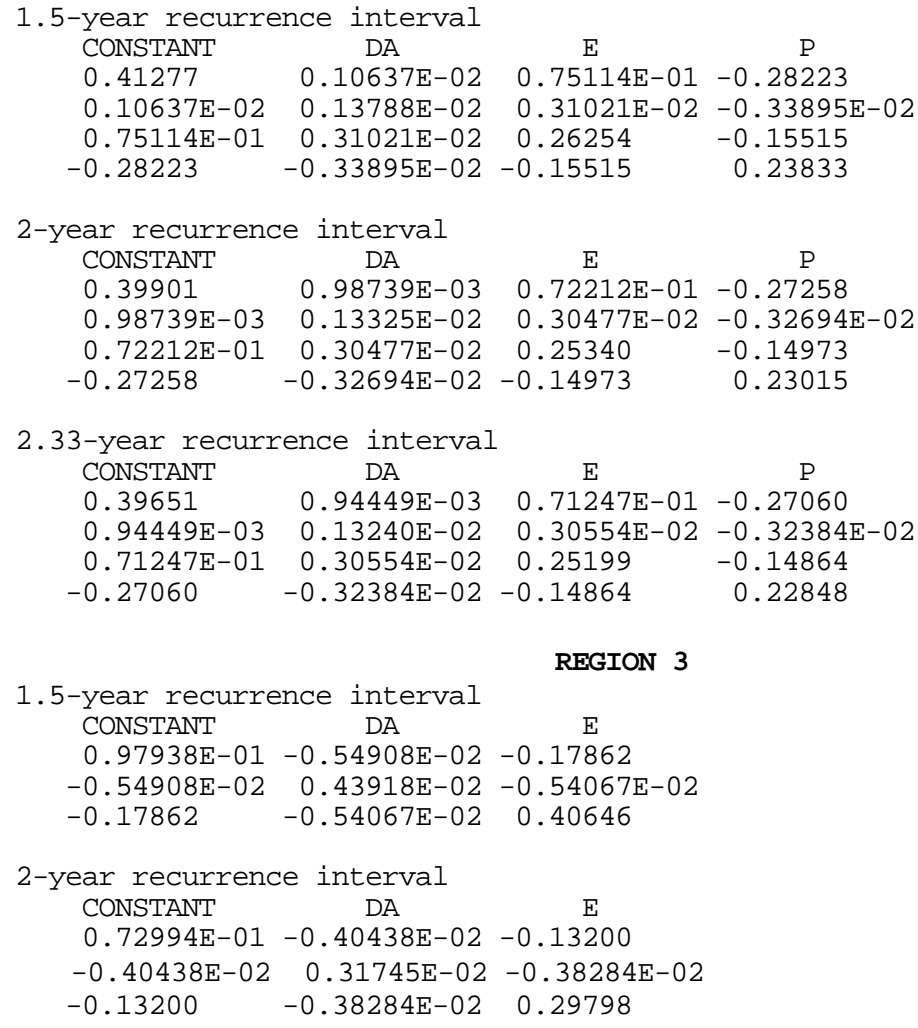


Appendix C. $\left(X^{\top} \Lambda^{-1} X\right)^{-1}$ matrices for the $T$-year $(T=1.5,2$, and 2.33) regional regression equations for Idaho-Continued

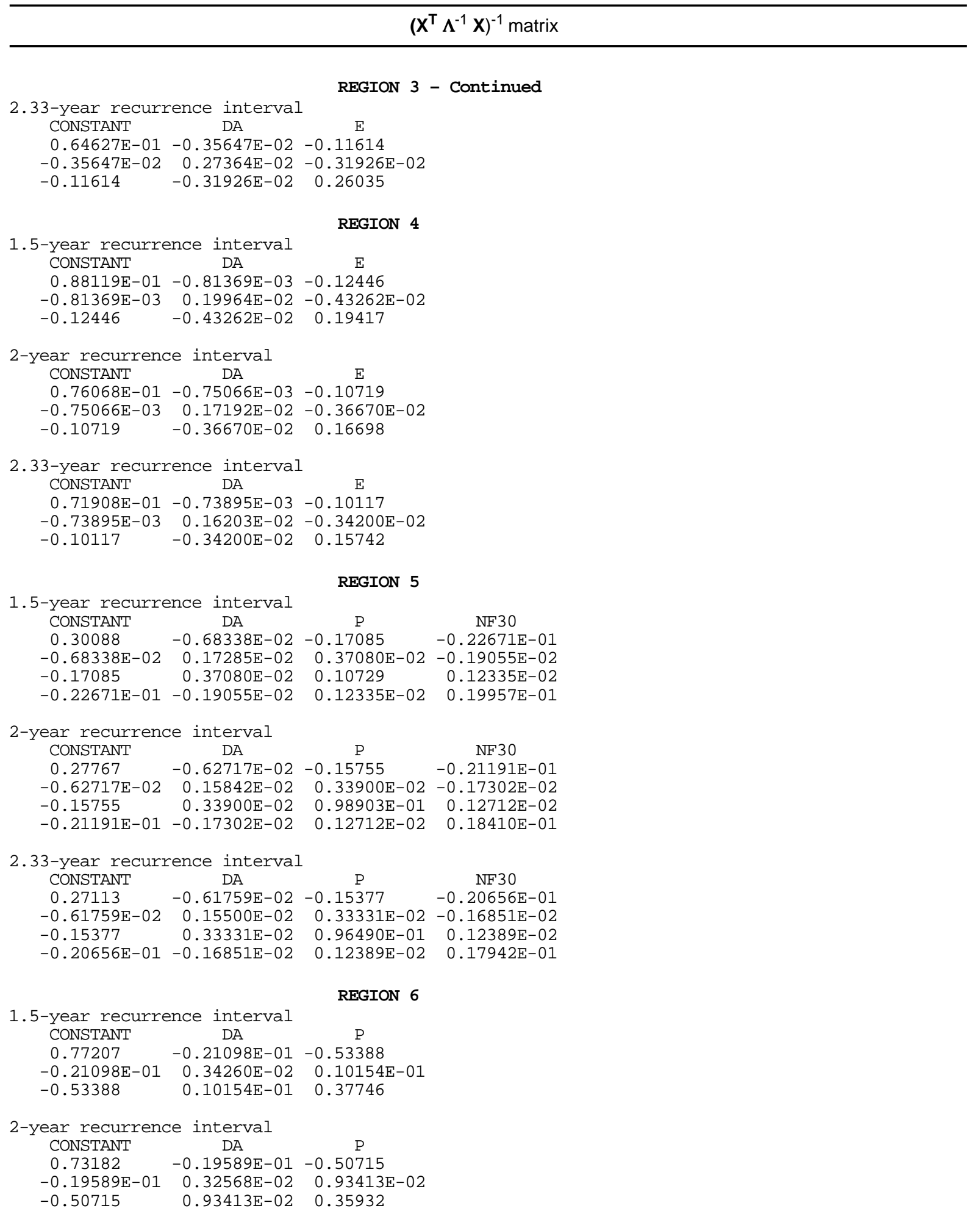


Appendix C. $\left(X^{\top} \Lambda^{-1} X\right)^{-1}$ matrices for the $T$-year $(T=1.5,2$, and 2.33) regional regression equations for Idaho-Continued

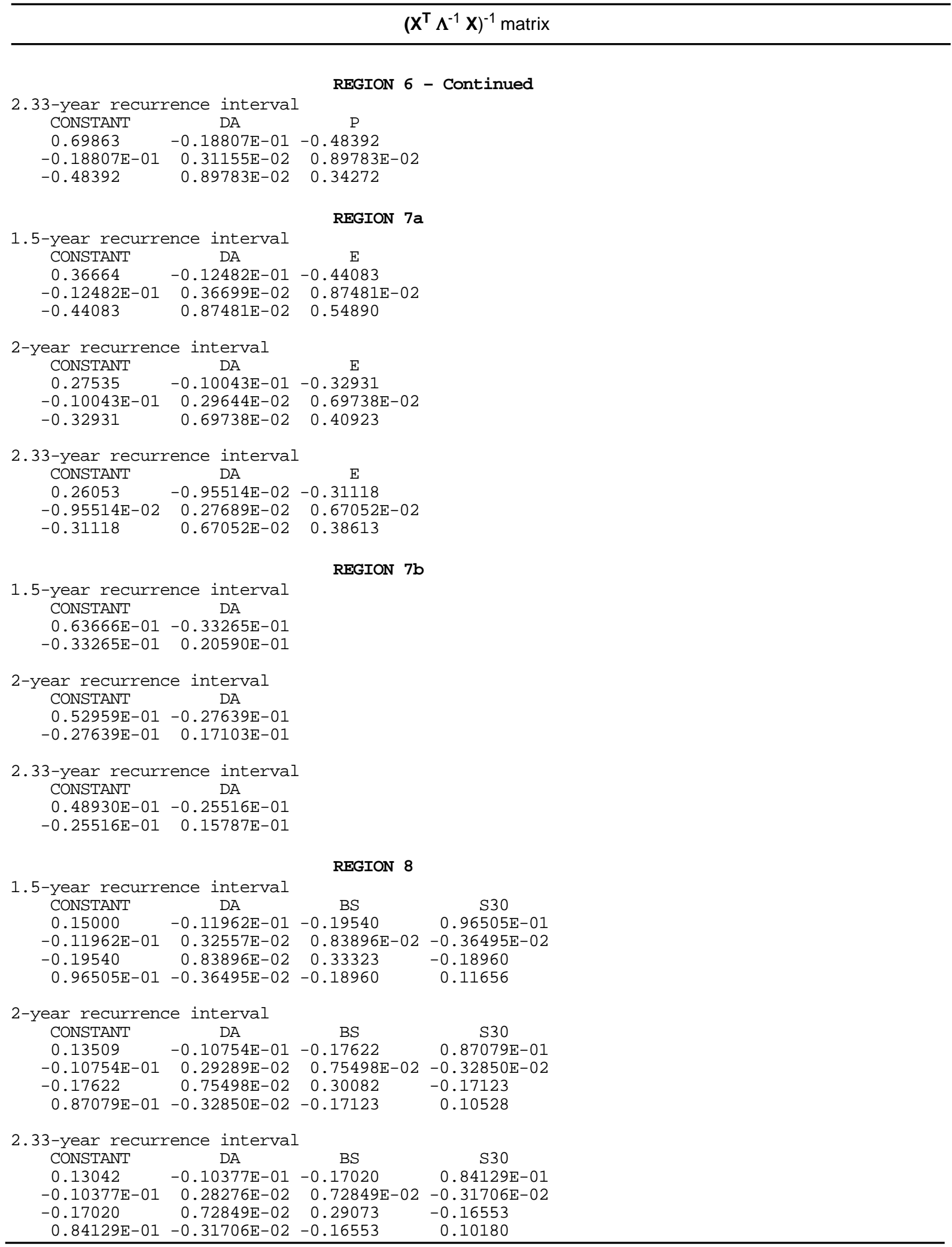


